\title{
Early Targeting of L-Selectin on Leukocytes Promotes Recovery after Spinal Cord Injury, Implicating Novel Mechanisms of Pathogenesis
}

\author{
D. A. McCreedy, ${ }^{1,3,4^{\wedge}}$ DS. Lee, ${ }^{1,2^{\wedge}}$ C. J. Sontag, ${ }^{1}$ P. Weinstein, ${ }^{1}$ A. D. Olivas, ${ }^{1}$ A. F. Martinez, ${ }^{1}$ T. M. \\ Fandel, ${ }^{1}$ A. Trivedi, $^{1}{ }^{\circledR}$ C. A. Lowell, ${ }^{4}$ ㅇ․ D. D. Rosen, ${ }^{5}$ and ${ }^{\circledR}$ L. J. Noble-Haeusslein ${ }^{1,6}$
}

DOI:http://dx.doi.org/10.1523/ENEURO.0101-18.2018

${ }^{1}$ Department of Neurological Surgery, University of California, San Francisco, CA 94143, ${ }^{2}$ Brain and Spinal Injury Center, University of California, San Francisco, CA 94110, ${ }^{3} \mathrm{~J}$. David Gladstone Institutes, University of California, San Francisco, CA 94158, ${ }^{4}$ Department of Laboratory Medicine, University of California, San Francisco, CA 94143, ${ }^{5}$ Department of Anatomy and Program in Immunology, University of California, San Francisco, CA 94143, and

${ }^{6}$ Department of Physical Therapy and Rehabilitation Science, University of California, San Francisco, CA 94143

\section{Visual Abstract}

Control
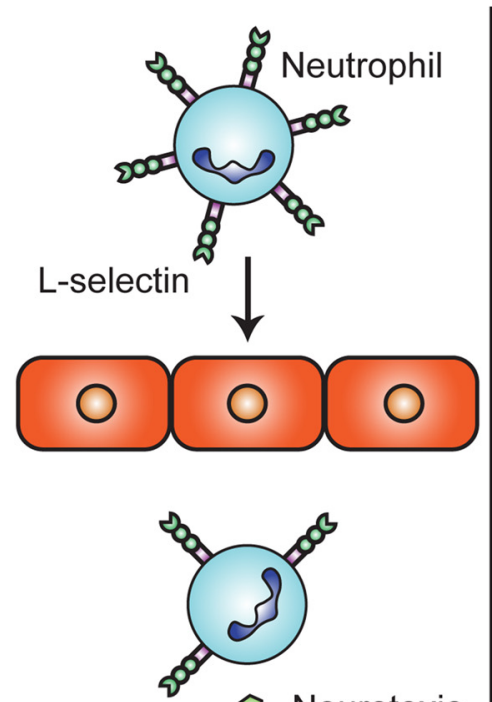

○ Neurotoxic substances

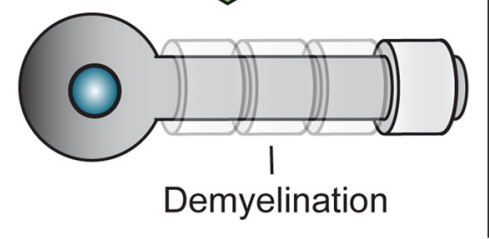

Knockout

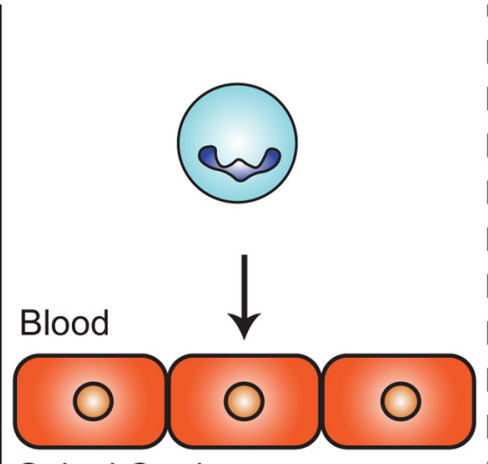

Spinal Cord

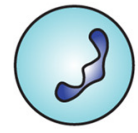

- Diminished L-selectin may reduce neurotoxic substances
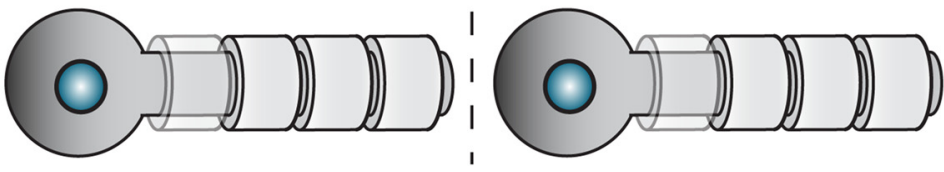

Reduced oxidative stress and demyelination 


\section{Significance Statement}

In this study, we establish L-selectin, an adhesion and signaling receptor on immune cells, as a determinant of long-term recovery and tissue sparing after spinal cord injury (SCl). We demonstrate that L-selectin contributes to secondary pathogenesis during acute inflammation, and implicate L-selectin in novel roles other than recruitment. We also report a strategy to improve recovery by employing diclofenac, an FDA-approved nonsteroidal anti-inflammatory drug (NSAID) that induces the shedding of L-selectin from the surface of innate immune cells. Our findings demonstrate a critical time-period for anti-inflammatory intervention in a murine model of $\mathrm{SCl}$ and suggest that diclofenac be tested as an acute therapy for attenuating neurologic deficits following $\mathrm{SCl}$ in humans.

L-selectin, a lectin-like receptor on all leukocyte classes, functions in adhesive and signaling roles in the recruitment of myeloid cells from the blood to sites of inflammation. Here, we consider L-selectin as a determinant of neurological recovery in a murine model of spinal cord injury (SCl). Spinal cord-injured, L-selectin knock-out (KO) mice (male) showed improved long-term recovery with greater white matter sparing relative to wild-type (WT) mice and reduced oxidative stress in the injured cord at $72 \mathrm{~h}$ post-SCl. There was a partial and transient reduction in accumulation of neutrophils in the injured spinal cords of KOs at $24 \mathrm{~h}$ post-injury. To complement these findings with $\mathrm{KO}$ mice, we sought a pharmacologic means for lowering L-selectin levels. We found that diclofenac, a nonsteroidal anti-inflammatory drug (NSAID), induced the shedding of L-selectin from the cell surface of myeloid subsets, specifically neutrophils and non-classical monocytes, in the blood and the injured spinal cord. Diclofenac administration to injured WT mice enhanced neurological recovery to a level comparable to that of KOs but did not improve recovery in KOs. While diclofenac treatment had no effect on myeloid cell accumulation, there was a reduction in oxidative stress at $72 \mathrm{~h}$ post-SCl. These findings implicate L-selectin in secondary pathogenesis beyond a role in leukocyte recruitment and raise the possibility of repurposing diclofenac for the treatment of SCl.

Key words: diclofenac; L-selectin; leukocytes; myelin; oxidative stress; spinal cord injury

\section{Introduction}

Spinal cord injury (SCl) results in partial or complete loss of motor and sensory function below the site of injury. The neurologic deficits resulting from $\mathrm{SCl}$ are not solely

Received March 16, 2018; accepted August 3, 2018; First published August 13, 2018.

The authors declare no competing financial interests.

Author contributions: D.A.M., S.L., C.J.S., P.W., A.D.O., T.M.F., A.T., C.A.L., S.D.R., and L.J.N.-H. designed research; D.A.M., S.L., C.J.S., A.D.O., A.F.M., T.M.F., and A.T. performed research; D.A.M., S.L., C.J.S., A.D.O., A.F.M., T.M.F., A.T., and L.J.N.-H. analyzed data; D.A.M., S.L., C.J.S., P.W., C.A.L., S.D.R., and L.J.N.-H. wrote the paper.

This work was supported by the Department of Defense Grant SCIRP W81XWH-12-1-0563, the Craig H. Neilsen Foundation, the Dana Foundation, the Oxnard Foundation of California, the Roman Reed Fund from the State of California, the National Institutes of Health, National Institute of Neurological Disorders and Stroke (NINDS) Grants R01NSC39278 and F32NS096883, and the University of California San Francisco Sandler Foundation in Basic Science Integrative Research Award.

${ }^{\wedge}$ D.A.M. and S.L. are co-first authors.

Acknowledgements: We thank Tjoson Tjoa for his contributions to model generation, histology, and animal care and Mark Singer for his assistance during the early stages of the work. Behavioral data were obtained with support from the University of California San Francisco Neurobehavioral Core for Rehabilitation Research.

Correspondence should be addressed to Dr. Dylan A. McCreedy, University of California, San Francisco, 513 Parnassus Avenue, HSW-1201A, San Francisco, CA 94143, E-mail: dylan.mccreedy@gladstone.ucsf.edu.

DOI:http://dx.doi.org/10.1523/ENEURO.0101-18.2018

Copyright (C) 2018 McCreedy, Lee et al.

This is an open-access article distributed under the terms of the Creative Commons Attribution 4.0 International license, which permits unrestricted use, distribution and reproduction in any medium provided that the original work is properly attributed. attributed to the initial mechanical damage, and there is a broad consensus that early infiltrating leukocytes, primarily myeloid lineage cells (i.e., neutrophils and monocytes), release neurotoxic substances including reactive oxygen species (ROS), proteases, and proinflammatory cytokines that cause secondary tissue damage (Chatzipanteli et al., 2002; Noble et al., 2002; Bareyre and Schwab, 2003; David and Kroner, 2011). Various strategies, directed at attenuating the early recruitment of myeloid cells from the blood into the injured spinal cord, have shown promising results for reducing cell injury and improving long-term neurologic outcomes (Popovich et al., 1999; Gris et al., 2004; Popovich and Longbrake, 2008; Lee et al., 2011; Zhang et al., 2011). However, inconsistent benefits or deleterious consequences have been observed in other studies (Stirling et al., 2009; Hurtado et al., 2012). These discrepancies may be due to opposed reparative and damaging activities in the targeted myeloid subsets. In the present study, we have identified L-selectin, a leukocyte adhesion/signaling receptor, as a novel therapeutic target in $\mathrm{SCl}$.

Selectins are C-type lectins that generally function sequentially with integrins during the multistep process of leukocyte recruitment from the blood into sites of inflammation (Ley et al., 2007; McEver, 2015). The vascular selectins, E- and P-selectin, are upregulated on inflamed vascular endothelium and bind to ligands such as P-selectin glycoprotein ligand-1 (PSGL-1) on leukocytes (McEver, 2015). L-selectin (CD62L) on lymphocytes mediates their rolling on high endothelial venules during 
homing to secondary lymphoid organs through the interaction of its lectin domain with carbohydrate-based ligands on this specialized endothelium (Rosen, 2004). L-selectin is also broadly expressed on circulating myeloid leukocytes and has adhesive and signaling activities that underlie various responses of these cells to inflammation (Ley et al., 2007; McEver, 2015). Studies employing knock-out (KO) mice or blocking antibodies have demonstrated that L-selectin, working in concert with vascular selectins, is involved in the recruitment of myeloid cells from the blood into various sites of inflammation (Lewinsohn et al., 1987; Pizcueta and Luscinskas, 1994; Tedder et al., 1995; Ley et al., 2007; Zuchtriegel et al., 2015).

It is now clear that L-selectin contributes to myeloid cell recruitment as a secondary adhesion molecule that mediates tethering between endothelial-adherent leukocytes and circulating leukocytes, via binding in trans to PSGL-1 on leukocytes (Walcheck et al., 1996; Sperandio et al., 2003), and as a signaling molecule that augments the activation of integrins on rolling leukocytes (Stadtmann et al., 2013; Morikis et al., 2017). Additional activities, apart from the recruitment of leukocytes from the blood, are indicated in that the ligation of L-selectin on neutrophils by soluble carbohydrate ligands, such as carcinoma-derived or salivary mucins, potentiates the degranulation of these cells (Shao et al., 2011; Mohanty et al., 2015). In the context of CNS inflammation, the possibility of a post-recruitment role for L-selectin has emerged based on the observation that L-selectin mediates the in vitro adhesion of leukocytes to myelinated fiber tracts in the CNS (Huang et al., 1991, 1994). In light of its potential recruitment and postrecruitment activities, we have investigated whether the reduction of L-selectin function through genetic or pharmacologic means has an impact on neurologic recovery in a murine model of SCl.

We demonstrate that complete L-selectin deficiency results in a partial reduction of neutrophil accumulation and oxidative stress in the acutely injured cord as well as improved long-term neurologic recovery that corresponds to greater sparing of white matter. We further show that diclofenac, an nonsteroidal anti-inflammatory drug (NSAID) and an inducer of L-selectin shedding from the leukocyte cell surface (Díaz-González et al., 1995; Gómez-Gaviro et al., 2002), has beneficial effects in SCl comparable to the genetic elimination of L-selectin. Since diclofenac is currently approved by the FDA (Altman et al., 2015), there could be an opportunity to repurpose this drug for the spinal cord-injured patient. The beneficial consequences of reducing $L$-selectin levels cannot be attributed solely to reduced leukocyte recruitment, particularly in the case of diclofenac, highlighting the consideration of L-selectin in novel roles in secondary pathogenesis and subsequent long-term neurologic deficits.

\section{Materials and Methods}

\section{Animals}

These studies were approved by the Institutional Animal Care and Use Committee at the University of California San Francisco and were in accordance with the United States Department of Agriculture guidelines. Homozy- gous L-selectin KO mice and their wild-type (WT) littermates were generated by breeding heterozygous males and females on a C57BI/6 background. We confirmed that mice from L-selectin KO and WT colonies did not contain the recently reported copy number variant in the Dock2 allele (Mahajan et al., 2016). WT and KO littermates were then studied with the exception of flow cytometry experiments where WTs were purchased from The Jackson Laboratory. WT mice for diclofenac studies were purchased from Jackson Laboratories. Mice were housed in groups of two to five before injury and singly housed after $\mathrm{SCl}$.

\section{$\mathrm{SCl}$}

Adult male mice (approximately three to five months of age) were anesthetized with $2.5 \%$ Avertin $(0.02 \mathrm{ml} / \mathrm{g}$ body weight, i.p., tribromoethanol; Sigma) or $2 \%$ isoflurane and subjected to a spinal cord contusion injury as described previously (Lee et al., 2011). Briefly, a laminectomy was performed at the ninth thoracic vertebra and a 3-g weight was dropped $5-7.5 \mathrm{~cm}$ onto the exposed dura mater to produce the SCl. After injury, the skin was closed with wound clips. Body temperature was maintained at $37^{\circ} \mathrm{C}$ with a warming blanket throughout the surgery and during recovery from anesthesia. Postoperative care included subcutaneous administration of saline and antibiotics daily for $10 \mathrm{~d}$ and manual expression of the bladder twice per day until euthanasia.

\section{Treatment with diclofenac}

Diclofenac (Sigma) was dissolved in PBS at $2.5 \mathrm{mg} / \mathrm{ml}$ and sterile filtered before use. To determine whether diclofenac modulates neurologic recovery after $\mathrm{SCl}$, diclofenac $(20,30$, or $40 \mathrm{mg} / \mathrm{kg})$ was administered intraperitoneally immediately, $3 \mathrm{~h}$, or $8 \mathrm{~h}$ after $\mathrm{SCl}$. The dosing was based on previous studies in rodents (Grace et al., 2001). Behavioral tests were performed as described below.

\section{Assessment of neurologic recovery}

Two behavioral tests, Basso Mouse Scale (BMS) and grid walk, were performed in the same mice to evaluate functional improvements after SCl. The nine-point BMS was used to examine locomotor recovery in an open field $(53 \times 108 \times 5.5 \mathrm{~cm}$; Basso et al., 2006). This rating scale takes into account limb movement, stepping, coordination, and trunk stability. Mice were tested at 1, 3, and $7 \mathrm{~d}$ and weekly thereafter until euthanasia at five to six weeks post-SCI. For studies examining diclofenac in WTs, mice achieving a BMS score $\geq 1$ at $1 \mathrm{~d}$ post-SCl were considered insufficiently injured and were removed from the analysis. For grid walking, a mouse (with a BMS score of four or greater) was positioned on a grid, divided into $0.5-\mathrm{cm}$ squares, and the number of foot faults was recorded over a period of $3 \mathrm{~min}$. A foot fault was evident when a paw fully extended through a space in the grid. The grid walking test was performed over $3 \mathrm{~d}$ at approximately five weeks post-SCI with three trials per day.

\section{Measurement of white matter sparing}

Animals were euthanized at 35 or $42 \mathrm{~d}$ post-SCl and perfused with $50 \mathrm{ml}$ of PBS followed by $50 \mathrm{ml}$ of $4 \%$ 
paraformaldehyde $(\mathrm{pH}$ 7.4). The spinal cords were removed, postfixed overnight, and cyroprotected in 30\% sucrose for $4 \mathrm{~d}$. Cords were then embedded and frozen at $-80{ }^{\circ} \mathrm{C}$ until sectioning; $20-\mu \mathrm{m}$ transverse sections were made on a cryostat, and serial sections, $500 \mu \mathrm{m}$ apart, were chosen for staining of white matter using either luxol fast blue (LFB) or eriochrome cyanine. Sections were evaluated by light microscopy and the one with the least spared white matter was selected as the lesion epicenter. For sections stained with LFB, the area of residual white matter was hand-traced using Neurolucida software (Microbrightfield Bioscience) and the percentage of spared white matter relative to the total cross sectional area of the cord at the epicenter was determined (Lee et al., 2011). This epicenter measurement has previously been demonstrated to correlate with injury severity and the degree of functional recovery (Kuhn and Wrathall, 1998). For sections stained with eriochrome cyanine, the area of residual white matter at the epicenter was traced and quantified using the Stereolnvestigator (MBF Bioscience) Cavalieri probe.

\section{Immunoblotting}

A $0.5 \mathrm{~cm}$ length of cord, centered over the site of impact and representing the epicenter, was homogenized in Glo lysis buffer (Promega) or RIPA buffer (Thermo Fisher). The protein concentration in homogenates was determined by the BCA protein assay kit (Pierce). For detecting malondialdehyde (MDA), we used the OxiSelect Malondialdehyde immunoblot kit (Cell BioLabs, Inc.) according to the manufacturer's protocol. Briefly, $20 \mu \mathrm{g}$ of protein was loaded onto 12-15\% SDS-PAGE gel and transferred onto a nitrocellulose or PVDF membrane. After blocking the membrane with 1\% BSA solution, the membrane was incubated with rabbit anti-MDA antibody overnight. The membrane was washed with Tris-buffered saline including $0.1 \%$ triton $\mathrm{X}-100$ and then incubated with anti-rabbit-HRP antibody for $1 \mathrm{~h}$. MDA-positive bands were detected using Pierce SuperSignal West Pico Chemiluminescent substrate (Thermo Fisher Scientific). Bands at $\sim 65 \mathrm{kDa}$, including both bands for uninjured (UN) control samples, were measured. For all of the comparisons, $\beta$-actin (Sigma, RRID:AB_476744) or GAPDH (Millipore, RRID:AB_2107426) served as a loading control and was used for normalization.

\section{Cell isolation and treatments}

Neutrophils were isolated from peripheral blood of mice by Ficoll-Paque (Ficoll-Paque PREMIUM 1.084, GE Healthcare Bio-Sciences AB) according to manufacturer's protocol. Briefly, $2 \mathrm{ml}$ of peripheral blood were obtained by cardiac puncture from three mice and mixed with $10 \mathrm{ml}$ of HBSS. After addition of $3 \mathrm{ml}$ of Ficoll-Paque, the sample as subjected to density-gradient centrifugation of 30 $\min$ at $400 \times g$ at room temperature (RT). Neutrophils were carefully collected from upper layers. To purify the neutrophil-enriched fraction, erythrocytes were lysed with RBC lysis buffer at RT (eBioscience). The purity of the neutrophil fraction was $\geq 90 \%$.

To investigate whether NSAIDs induce L-selectin shedding, the isolated cells were treated with NSAIDs as pre- viously described (Gómez-Gaviro et al., 2002). Cells were resuspended in PBS and incubated either alone or in the presence of diclofenac $(20-500 \mu \mathrm{g} / \mathrm{ml})$ or meclofenamic acid (MFA; $20-500 \mu \mathrm{g} / \mathrm{ml}$, Sigma) for $30 \mathrm{~min}$ at $37^{\circ} \mathrm{C}$. PMA $(250 \mathrm{ng} / \mathrm{ml})$ served as a positive control. All NSAIDs were dissolved in PBS. Then cells were analyzed by flow cytometry and the supernatants were analyzed for soluble L-selectin (sL-selectin) by enzyme-linked immunosorbent assay (sL-selectin ELISA section). Data were collected from seven independent experiments for flow cytometry and two independent experiments for ELISA.

\section{Flow cytometry}

For neutrophils and mononuclear cells exposed to NSAIDs, the cells were washed with PBS then incubated with anti-mouse CD16/32 Fc blocking antibody (1:10 dilution; eBioscience, RRID:AB_467133) for 10 min followed by anti-CD62L Ab conjugated with PE (1:10 dilution, Mel-14 clone, eBioscience, RRID:AB_465720) for $30 \mathrm{~min}$ at $4^{\circ} \mathrm{C}$. After washing in PBS, the cells were analyzed in a FACScan flow cytometer (Becton Dickinson) and FlowJo software (Tree Star Inc.). In all in vitro experiments, at least $10^{6}$ cells were analyzed for flow cytometry. Cell viability was determined by 7-amino-acinomycin D staining (7AAD; BD Bioscience). Data were collected from seven independent experiments.

For in vivo experiments, blood samples were obtained by cardiac puncture using a heparin-primed syringe from uninjured and spinal cord-injured mice. Recruitment of leukocytes from the blood into spinal cord can occur across blood vessels in the meninges or parenchymal tissue (Ransohoff et al., 2003). Injured mice were perfused with $25 \mathrm{ml}$ of ice cold PBS to remove free leukocytes within blood vessels. From each animal, a 5-mm region of spinal cord (with associated meninges) centered over the injury site was removed and stored in ice cold RPMI media. The spinal cord segment was then mechanically dissociated using a plastic tissue pestle. The suspension was filtered through a 100- $\mu \mathrm{m}$ nylon mesh filter, and the filtrate was centrifuged at $300 \times \mathrm{g}, 4^{\circ} \mathrm{C}$ for $5 \mathrm{~min}$. Blood and spinal cord samples were then lysed with $1 \mathrm{ml}$ of $1 \times$ RBC lysis buffer (eBioscience) for $5 \mathrm{~min}$ at $4^{\circ} \mathrm{C}$, followed by the addition of $10 \mathrm{ml}$ of FACS buffer (0.5 $\mu \mathrm{M}$ EDTA, $2 \%$ fetal bovine serum, and HBSS; pH 7.4). The cell suspension was centrifuged and the pellet was re-suspended in $10 \mathrm{ml}$ of HBSS and centrifuged again. Live/dead cell staining was then performed by incubating samples with Ghost Dye Red 780 (1:1000, Tonbo Biosciences) for 30 $\min$ at $4^{\circ} \mathrm{C}$. Samples were washed with $10 \mathrm{ml}$ of FACS buffer, centrifuged, and the supernatant was discarded. Cells were then resuspended in FACS buffer and incubated with anti-mouse CD16/32 Fc blocking antibody (1:100 dilution; eBioscience, RRID:AB_467133) at $4^{\circ} \mathrm{C}$ for 20 min. Next, samples were washed with $10 \mathrm{~mL}$ of FACS buffer and $1 \mathrm{ml}$ was partitioned for isotype control staining. Samples were then centrifuged and the pellets were incubated with a cocktail of the following antibodies: FITC-conjugated rat anti-mouse CD62L (1:100 dilution, Mel-14 clone, BioLegend, RRID:AB_313093), Pacific Blue-conjugated rat anti-mouse Ly-6G (1:200 dilution, 
1 A8 clone, BioLegend, RRID:AB_2251161), APC-conjugated rat anti-mouse CD11b (1:200 dilution, M1/70 clone, BioLegend, RRID:AB_312795), PE-conjugated rat anti-mouse CD45 (1:200 dilution, 30-F11 clone, Tonbo, RRID:AB_2621763), and PerCP/Cy5.5-conjugated rat anti-mouse Ly-6C (1:600 dilution, HK1.4 clone, BioLegend, RRID:AB_1659241). FITC-conjugated rat IgG2a, $\kappa$ (1:100 dilution, BioLegend, RRID:AB_2736919) served as the isotype control for CD62L. After incubating with antibodies for $30 \mathrm{~min}$ at $4^{\circ} \mathrm{C}$, samples were washed with FACS buffer, centrifuged, and the pellets were resuspended in $200 \mu \mathrm{l}$ of FACs buffer. Flow cytometry was performed on the cell suspensions using a Fortessa flow cytometer (Becton Dickinson).

The data were analyzed using FlowJo software. At least 50,000 events were analyzed for blood samples, and all of the collected events were analyzed for spinal cord samples. Cells (low SSC, high FSC) were gated from debris (high SSC, low FSC) as previously described (Stirling and Yong, 2008). The geometric mean fluorescent intensity (G-MFI) values for CD62L were calculated to determine the overall presence of $\mathrm{L}$-selectin on the surface of leukocytes. Since staining histograms for L-selectin were often skewed, we used G-MFI instead of arithmetic MFI to represent the data. This parameter better reflects the central tendency of skewed distributions. Isotype G-MFI were determined for each sample and subtracted from the reported G-MFI values. Total leukocyte and myeloid lineage subset counts from spinal cord samples were extrapolated to the total volume of cells to account for the volume of cells removed for isotype staining.

\section{sL-selectin ELISA}

To determine whether diclofenac treatment induces L-selectin shedding, blood was obtained by cardiac puncture at $0,2,8,24$, and $48 \mathrm{~h}$ after intraperitoneal administration of this drug $(1,5,10,20,40$, or $60 \mathrm{mg} / \mathrm{kg})$ immediately following $\mathrm{SCl}$ produced by dropping a $2 \mathrm{~g}$ weight from a distance of $5 \mathrm{~cm}$. After centrifugation at $2000 \times g$ for 20 min at RT, plasma was then collected for assessment using an ELISA kit (Quantikine, mouse sLSelectin, R\&D Systems) according to the manufacturer's instructions. All incubations were conducted at RT and for $2 \mathrm{~h}$ unless otherwise indicated. A total of $100 \mu \mathrm{l}$ of supernatants was first incubated with assay diluent buffer in a microplate. After rinsing, the preparation was then incubated in $100 \mu \mathrm{l}$ of SL-selectin conjugate, followed by addition of $100 \mu \mathrm{l}$ of substrate for $30 \mathrm{~min}$. The reaction was then stopped by addition of stop solution. Optimal density was read at 450-nm wavelength with correction at $540 \mathrm{~nm}$ using a microplate reader (Invitrogen).

\section{Experimental design and statistical analyses}

The primary goal of this study was to determine whether L-selectin contributes to inflammation and neurologic deficits following $\mathrm{SCl}$. We employed L-selectin $\mathrm{KO}$ mice and also evaluated the effect of diclofenac, an NSAID that induces L-selectin shedding, on inflammation and neurologic recovery after $\mathrm{SCl}$ (Table 1). For all studies, only adult male mice were used to eliminate gender as
Table 1. Number of animals

\begin{tabular}{|c|c|c|}
\hline & WT $(N)$ & $\mathrm{KO}(N)$ \\
\hline \multicolumn{3}{|l|}{ Long-term studies } \\
\hline $\mathrm{SCl}$ & 21 & 24 \\
\hline BMS & 21 & 24 \\
\hline Grid-walk & 13 & 8 \\
\hline White matter sparing & 11 & 8 \\
\hline \multicolumn{3}{|l|}{ Acute studies } \\
\hline Uninjured & 7 & 7 \\
\hline $\mathrm{SCl}$ & 19 & 19 \\
\hline Immunoblotting & 8 & 8 \\
\hline \multirow[t]{2}{*}{ Flow cytometry } & 18 & 18 \\
\hline & Vehicle $(N)$ & Diclofenac $(N)$ \\
\hline \multicolumn{3}{|l|}{ Long-term studies } \\
\hline $\mathrm{SCl}(\mathrm{WT})$ & 75 & 122 \\
\hline $\mathrm{SCl}(\mathrm{KO})$ & 6 & 5 \\
\hline BMS & 79 & 109 \\
\hline Grid walk & 4 & 11 \\
\hline White matter sparing & 14 & 28 \\
\hline Mortality (single dose) & 2 & 1 \\
\hline Mortality (two doses) & N/A & 8 \\
\hline Mortality (three doses) & N/A & 9 \\
\hline \multicolumn{3}{|l|}{ Acute studies } \\
\hline In vitro & \multicolumn{2}{|c|}{21 (pooled) } \\
\hline Uninjured & 18 & 18 \\
\hline $\mathrm{SCl}$ & 29 & 107 \\
\hline Flow cytometry & 25 & 25 \\
\hline ELISA & 17 & 95 \\
\hline Immunoblotting & 5 & 5 \\
\hline
\end{tabular}

a variable. Time points for collection of data and experimental endpoints were predetermined based on previous experience. Sample sizes were determined by our previous experience with BMS scoring and immunoblotting (Lin et al., 2007; Lee et al., 2011; Whetstone et al., 2017), and by power analyses for flow cytometry studies and sL-selectin assays (effect sizes were 500 G-MFI units and $550 \mathrm{ng} / \mathrm{ml}$, respectively, based on our own preliminary studies). For all studies, we anticipated a $\sim 10 \%$ mortality rate, based on previous experience in our lab (Whetstone et al., 2017) and substantiated in Figure 10/, and we adjusted the samples sizes accordingly. To control for potential variation in the $\mathrm{SCl}$ surgery and behavioral analyses, all studies were conducted with the surgeon and observers blinded to the genotype and/or experimental condition. Simple or block randomization was used for all in vivo studies.

Statistical analyses were performed using GraphPad Prism (GraphPad Software). Flow cytometry was evaluated by unpaired two-tailed Student's $t$ tests or one-way ANOVA followed by Tukey's post hoc test. ELISA data were evaluated by one-way ANOVA followed by a Dunnett's post hoc test. A two-way, repeated measures ANOVA followed by Sidak's multiple comparisons test was used to evaluate BMS scores. Comparison of two groups (foot faults, spared white matter, and immunoblots) was by an unpaired two-tailed Student's $t$ test. $\chi^{2}$ analysis was used to compare the number of animals stepping in the open field followed by a one-sided Fish- 

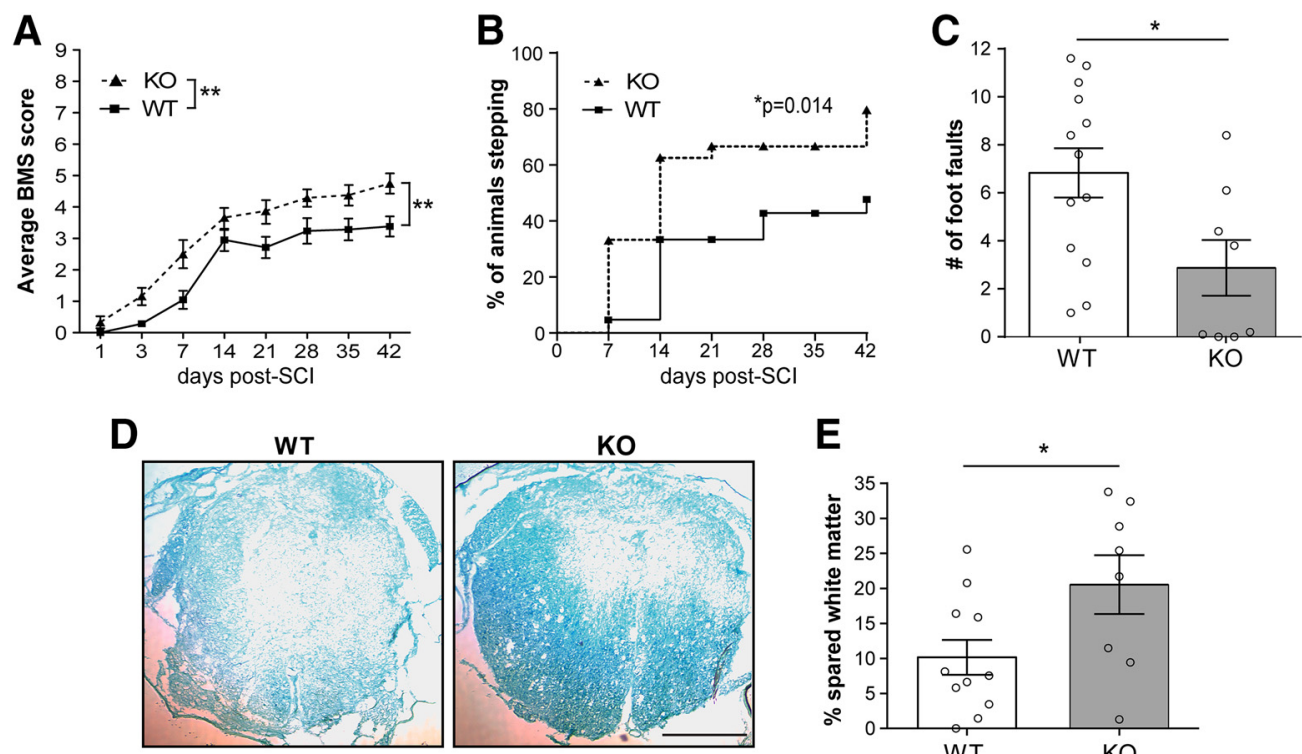

E

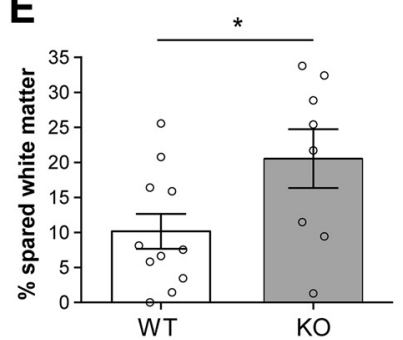

Figure 1. L-selectin $\mathrm{KO}$ mice show improved functional recovery and greater white matter sparing at $42 \mathrm{~d}$ after $\mathrm{SCl}$. $\boldsymbol{A}$, Functional recovery, as measured by the BMS open field test, was improved in KO mice. $N=21$ for WT and $N=24$ for KO combined from two independent cohorts of mice. Two-way ANOVA (interaction $p=0.11$; time $p<0.0001$; genotype $p=0.006$; $F_{(1,43)}=8.42$ ). $\boldsymbol{B}$, Stepping was improved in KO mice compared to WT mice. $N=21$ for WT and 24 for KO combined from two independent cohorts of mice. $\chi^{2}$ analysis followed by a one-sided Fisher's exact test. $* p=0.029$. $\boldsymbol{C}$, Performance on a grid, as measured by foot faults, was improved in the KO group. $N=13$ for WT and $N=8$ for KO. Two-tailed Student's $t$ test. $* p=0.023, t_{(19)}=2.48$. $\boldsymbol{D}$, Representative transverse sections at the lesion epicenter, stained with LFB, of injured WT and KO mice at $42 \mathrm{~d}$ post-SCI. Scale bar $=500 \mu \mathrm{m}$. $\boldsymbol{E}$, Greater spared white matter at the lesion epicenter, expressed as proportional area, was observed in the KO group. $N=11$ for WT and $N=8$ for KO. Two-tailed Student's $t$ test. $* p=0.038, t_{(17)}=2.26$.

er's exact test. Comparison of two groups was performed by the Mann-Whitney test when at least one of the datasets failed the D'Agostino and Pearson omnibus normality test. Statistical significance was defined at $p \leq 0.05$. Data are expressed as mean \pm SEM.

\section{Data availability}

All data are available from the authors.

\section{Results}

\section{Functional recovery is improved in L-selectin KO mice}

To assess whether L-selectin is a determinant of recovery after $\mathrm{SCl}$, we first compared locomotion of spinal cordinjured L-selectin KO mice with WT littermate controls using the BMS. L-selectin $\mathrm{KO}$ mice, subjected to $\mathrm{SCl}$, showed a marked improvement in locomotor recovery compared to that of the WT group $(p=0.006$; Fig. $1 A)$. A subsequent secondary analysis revealed that $79.2 \%$ of $\mathrm{KO}$ animals achieved weight supported plantar stepping $(B M S \geq 4)$ compared to $47.6 \%$ of WT mice by $42 \mathrm{~d}$ post-SCl $(p=$ 0.029 ; Fig. 1B). We also determined the number of footfaults of mice crossing a wire grid, which reflects sensorimotor function and motor coordination (Schaar et al., 2010). Foot-faults were reduced by $57.9 \%$ in the $\mathrm{KO}$ relative to the WT group at 35 d post-SCI ( $p=0.023$; Fig. $1 C$ ).

Functional recovery has been previously associated with greater white matter sparing at the lesion epicenter (Kuhn and Wrathall, 1998). To determine whether L-selectin is associated with white matter damage, the percentage of spared white matter was compared between groups in transverse sections stained with LFB (Fig. 1D). Strikingly, the percentage of spared white matter at the lesion epicenter was 2.0-fold greater in the spinal cord-injured $\mathrm{KO}$ mice as compared to injured WT mice at $42 \mathrm{~d}$ post-SCI $(p=0.038$; Fig. 1E).

\section{L-selectin is a determinant of oxidative stress in the acutely injured cord}

Newly recruited neutrophils and monocytes/macrophages from the blood promote oxidative stress in the acutely injured cord (Lee et al., 2011). Since L-selectin is expressed on blood neutrophils and monocytes, we examined the impact of the absence of L-selectin on oxidative stress. Immunoblotting verified that MDA, a product of lipid peroxidation (Liu et al., 2001) and marker for acute oxidative stress (Esterbauer et al., 1991; Azbill et al., 1997; Hichor et al., 2018), was similarly present at very low levels in the uninjured spinal cords of mice of both genotypes ( $p=0.98$; Fig. 2 ). There was a $51 \%$ reduction in MDA in injured L-selectin KO mice compared to injured WT mice ( $p=0.026,3 d$ post-SCI).

\section{L-selectin is dynamically regulated on myeloid cells following injury}

In light of our findings with L-selectin $\mathrm{KO}$ mice, we employed flow cytometry to quantify the expression of L-selectin on circulating and spinal cord-infiltrated leukocytes after SCl. Peripheral blood leukocytes from uninjured WT mice were also analyzed to establish baseline L-selectin levels. Because of their prominent recruitment during the acute phase of SCl (Beck et al., 2010), we focused on myeloid cells $\left(\mathrm{CD} 45^{+} / \mathrm{CD} 11 \mathrm{~b}^{+}\right)$. We identified 

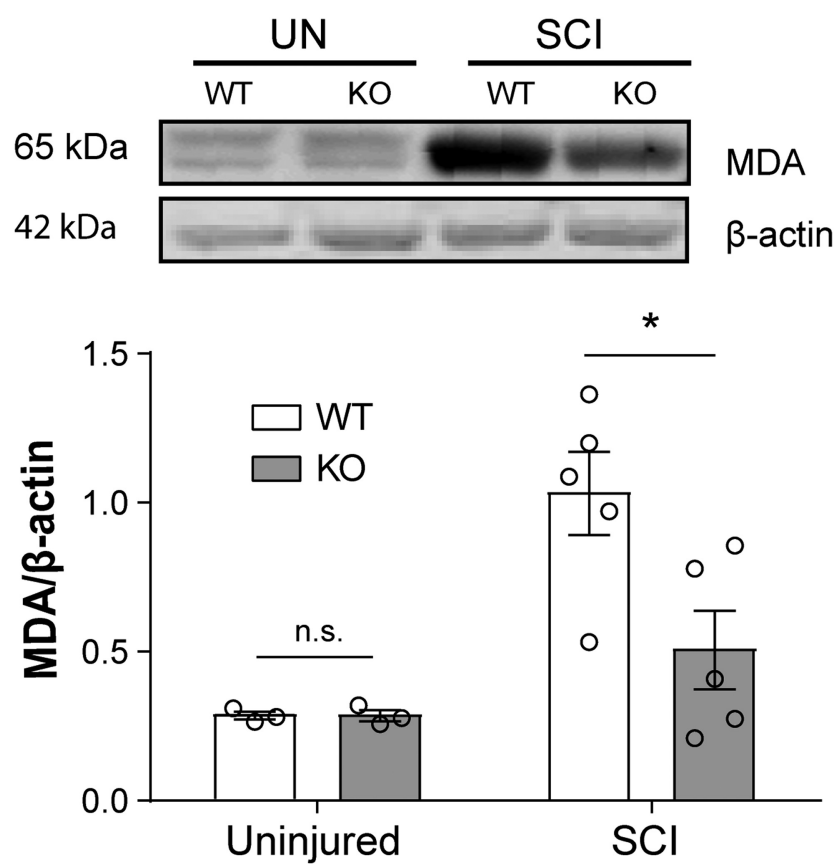

Figure 2. L-selectin is a determinant of early oxidative stress in the injured cord. Immunoblotting was performed on homogenates of uninjured (UN) and injured (SCl) cords from WT and $\mathrm{L}$-selectin $\mathrm{KO}$ mice at $3 \mathrm{~d}$ post-SCI. All values were normalized to $\beta$-actin. By immunoblotting, MDA was reduced in L-selectin KO mice by $51 \%$ compared to WT mice after SCl $\left(* p=0.026, t_{(8)}=\right.$ 2.73). $N=3 /$ genotype for $\mathrm{UN}$ and $N=5 /$ genotype for SCl. Unpaired two-tailed Student's $t$ test. For UN, $p=0.98, t_{(4)}=$ 0.02 .

leukocytes by gating for live (Ghost Dye $\mathrm{CD}^{-} \mathrm{C}^{+}$cells, then gated for myeloid cells $\left(\mathrm{CD} 11 \mathrm{~b}^{+}\right)$and subdivided them into neutrophils (Ly6Clow/Ly6G $\left.{ }^{+}\right)$, inflammatory/ classical monocytes ( $\left.\mathrm{Ly} \mathrm{C}^{\mathrm{hi}} / \mathrm{L} 6 \mathrm{G}^{-}\right)$, and patrolling/nonclassical monocytes (Ly6C low/Ly6G; Fig. 3A). For the monocyte populations in peripheral blood, $\mathrm{SCl}$ resulted in over 2-fold greater levels (G-MFI) of L-selectin (CD62L) on Ly6C ${ }^{\text {hi }} / \mathrm{LGG}^{-}$cells at 24 and $72 \mathrm{~h}$ post-SCl $(p<0.0001)$ and an increase of $49.4 \%$ on Ly6Clow/L6G cells at $72 \mathrm{~h}$ post-SCI $(p=0.048)$ compared to uninjured mice (Fig. $3 B, C)$. In contrast, L-selectin decreased by $25.3 \%$ on neutrophils (Ly6C low $/ \mathrm{Ly} 6 \mathrm{G}^{+}$cells) at $24 \mathrm{~h}$ post-SCl $(p=$ 0.007 ) but returned to baseline (uninjured) values by $72 \mathrm{~h}$ post-SCl. Leukocytes that accumulated in the spinal cord parenchyma at $24 \mathrm{~h}$ post-SCl exhibited two to 5 -fold reduced levels of L-selectin on the myeloid subtypes relative to levels on the corresponding cells in the blood (Fig. 4A); however, considerable L-selectin remained on the infiltrated cells for all subtypes, as established by comparison with corresponding cells in $\mathrm{KO}$ mice (Fig. $4 A$ ) and isotype controls (Fig. 4B). These data demonstrate that $\mathrm{L}$-selectin is present in varying degrees on all circulating myeloid lineages and is dynamically regulated after $\mathrm{SCl}$. Furthermore, considerable L-selectin is retained on infiltrated myeloid cells, where it could potentially be involved in post-recruitment adhesive or signaling events.

\section{L-selectin deficiency transiently reduces myeloid cell accumulation in the spinal cord}

As reviewed in the Introduction, L-selectin has been implicated in the recruitment of myeloid cells in multiple inflammatory settings. We therefore asked whether the lack of L-selectin could reduce trafficking of myeloid cells into the injured cord. We compared the number of leukocytes in injured spinal cords of L-selectin KO and WT mice. The accumulation of leukocytes in a particular tissue reflects recruitment from the blood and their turnover in the tissue. Using flow cytometry, we first determined the total number of infiltrated myeloid lineage cells $\left(\mathrm{CD} 45^{+} / \mathrm{CD} 11 \mathrm{~b}^{+}\right)$. We then used Ly6C and Ly6G antibodies to discriminate neutrophils and monocyte/microglia subtypes (Fig. 5A,B), and further subdivided the monocyte and resident microglia populations based on CD45 levels. Few $C D 11 b^{+}$cells were detected in the spinal cords of uninjured WT mice (650 \pm 103 cells) relative to injured WT mice at $24 \mathrm{~h}$ post-SCl $(13970 \pm 1920$ cells). At $24 \mathrm{~h}$ post-SCl, very few infiltrated $\mathrm{CD} 11 \mathrm{~b}^{+}$cells colabeled for T-cells $\left(213 \pm 60 \mathrm{TCR} \beta^{+}\right.$cells) or B-cells (357 $\pm 113 \mathrm{~B}^{2} 20^{+}$cells), confirming that $\mathrm{CD} 11 \mathrm{~b}^{+}$cells were predominantly myeloid cells. Furthermore, no differences in $\mathrm{CD} 45^{+} / \mathrm{CD} 11 \mathrm{~b}^{-}$cells (lymphocytes) were observed in the spinal cords of uninjured versus injured WT mice at 24 h post-SCI ( $485 \pm 186$ vs $532 \pm 178$ cells, $p=0.87)$. At $24 \mathrm{~h}$ post-SCl, we observed reductions of $29.9 \%$ and $26.4 \%$ of $\mathrm{CD} 11 \mathrm{~b}^{+}$cells $(p=0.028)$ and $\mathrm{Ly} 6 \mathrm{C}^{\text {low }} / \mathrm{LGG}^{+}$ cells $(p=0.038)$, respectively, but no significant effects on Ly6C $C^{\text {hi }} / \mathrm{LGG}^{-}$cells $(p=0.10)$ or $\mathrm{Ly} 6 \mathrm{C}^{\text {low}} / \mathrm{Ly} 6 \mathrm{G}^{-}$cells $(p=0.72)$ in the spinal cords of L-selectin KO mice compared to WTs (Fig. 5A,C). Clearly, the decrease in $\mathrm{CD}_{11} \mathrm{~b}^{+}$cells was mainly attributable to the Ly6Clow/ $\mathrm{L} 6 \mathrm{G}^{+}$cells (neutrophils), which comprised $\sim 72 \%$ of this population. The contributions of L-selectin to myeloid cell and neutrophil accumulation were limited in duration as there were no differences in these populations between $\mathrm{KO}$ and WT mice at $72 \mathrm{~h}$ post-SCI (Fig. 5B,D). No differences in the total number of CD $11 \mathrm{~b}^{+} / \mathrm{CD} 45^{\text {low }} / \mathrm{L} 6 \mathrm{G}^{-}$cells (microglia) were observed between WT and KO mice at 24 and 72 h post-SCI $(p=0.10$ and 0.38 , respectively; Fig. $5 E$ ). No differences were observed in the proportion of $\mathrm{CD} 11 \mathrm{~b}^{+}$cells and myeloid lineage subsets among total CD45 ${ }^{+}$leukocytes in the peripheral blood of WT and KO mice at 24 and $72 \mathrm{~h}$ post-SCl $(p>0.25$ for all subtypes; Fig. $5 F$ ). In summary, we found that $\mathrm{SCl}$ was associated with a massive influx of myeloid cells (21-fold increase) into the spinal cord and the absence of L-selectin resulted in a partial reduction in the accumulation of neutrophils at $24 \mathrm{~h}$, which was not sustained through $72 \mathrm{~h}$.

\section{NSAIDS differentially induce L-selectin shedding on murine leukocytes}

As an alternative to the genetic ablation of L-selectin, we sought a pharmacologic means to lower the cell surface levels of this receptor. A major mechanism for down-modulating L-selectin is through cleavage of the membrane proximal domain of $L$-selectin by cell surface metalloproteinases, such as ADAM17, causing the release (shedding) of the ligand-binding ectodomain into 
A $\underline{\text { Peripheral Blood - } 24 \text { hrs post-SCl }}$
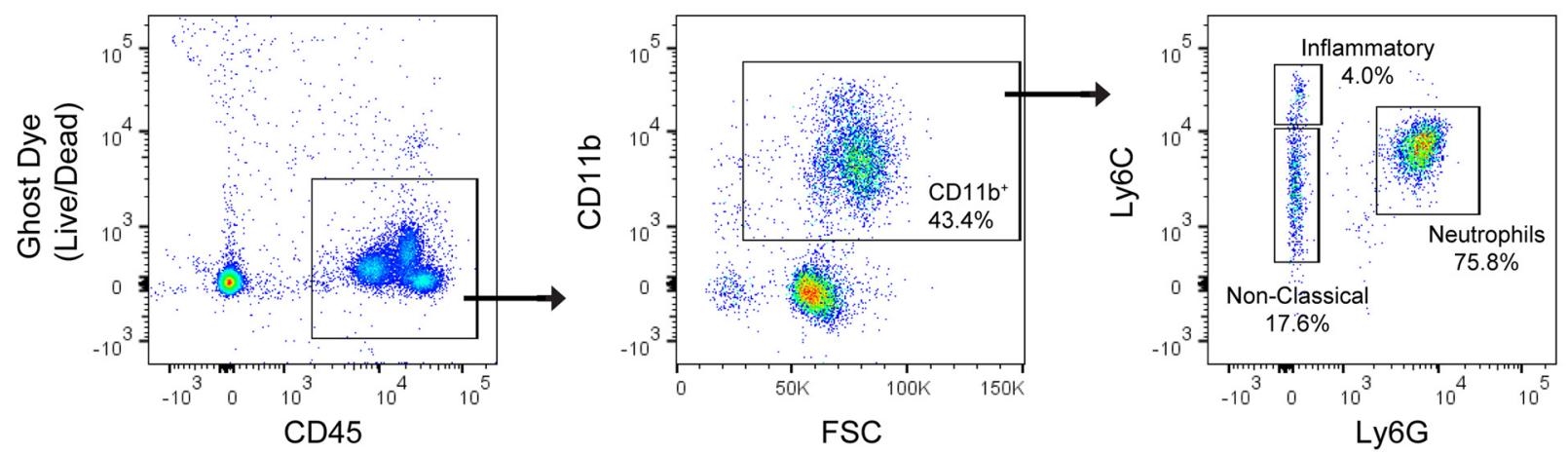

$\underline{\text { Peripheral Blood - } 72 \text { hrs post-SCl }}$

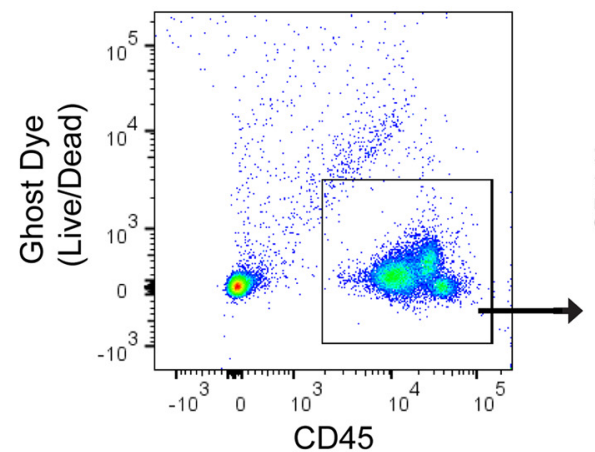

B
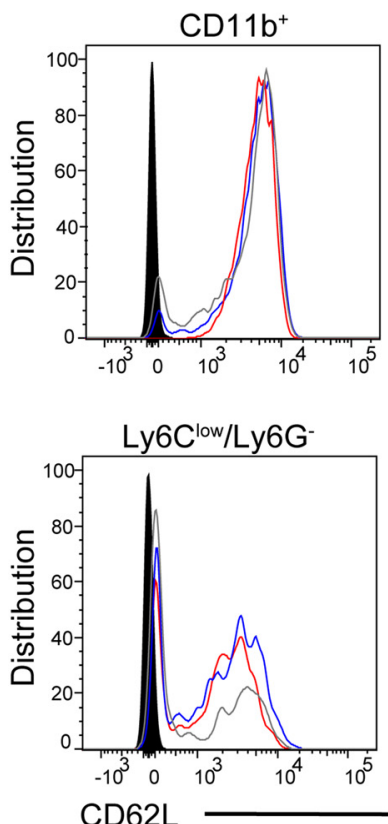

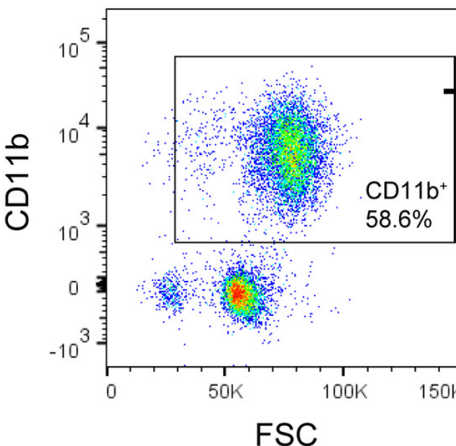

C

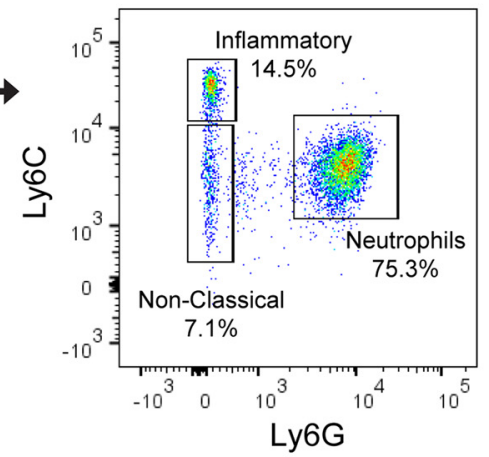

sotype $\square$ Uninjured
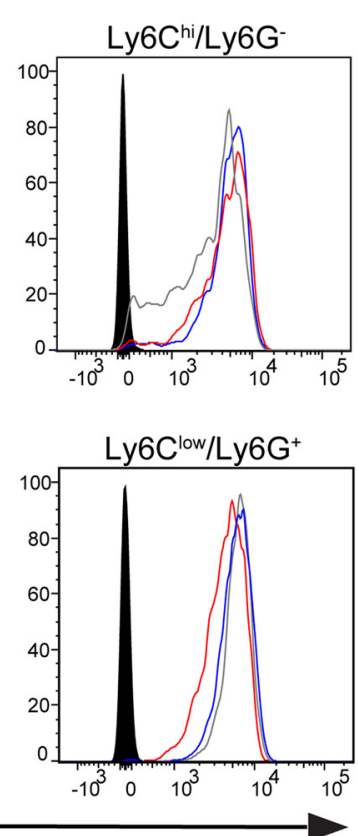

$\square$ Uninjured

$\mathrm{SCl} 24 \mathrm{hrs}$

$\mathrm{SCl} 72 \mathrm{hrs}$

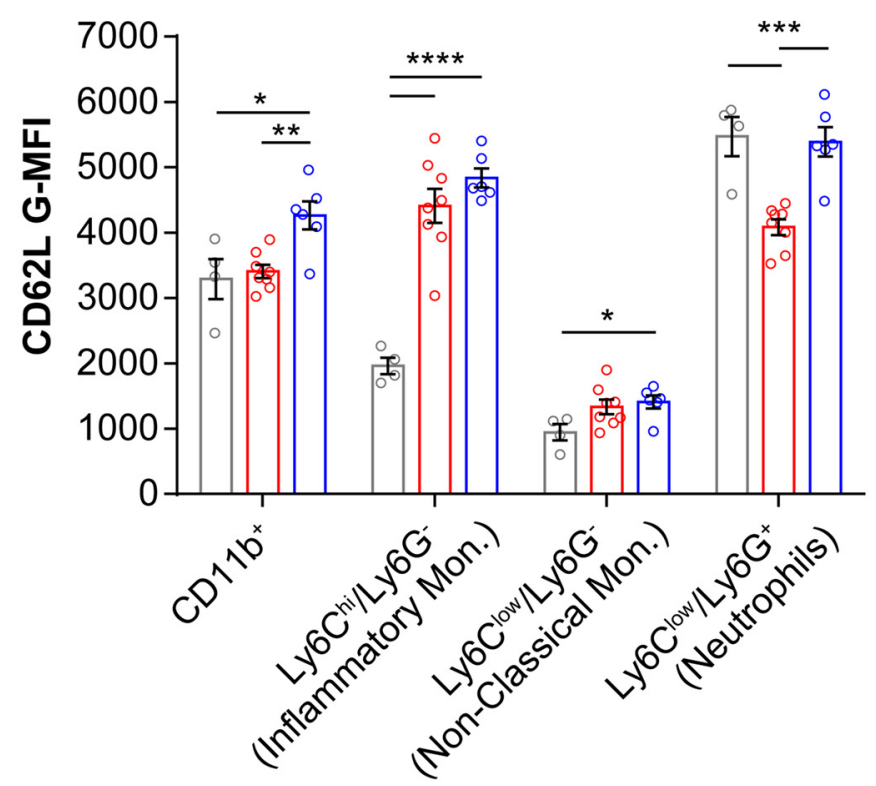

Figure 3. L-selectin is dynamically regulated after SCl. $\boldsymbol{A}$, Flow cytometry gating of leukocytes and leukocyte subsets in the peripheral blood at 24 and $72 \mathrm{~h}$ post-SCI. B, Representative flow cytometry histograms for CD62 L staining of myeloid cells in the peripheral blood from uninjured mice (gray line) and injured mice at $24 \mathrm{~h}$ (red line) and $72 \mathrm{~h}$ (blue line) post-SCl. Representative isotype staining is shown in solid black. $\mathbf{C}$, L-selectin (CD62L) levels on myeloid lineage cells in the peripheral blood from uninjured WT mice, and injured WT mice at 24 and $72 \mathrm{~h}$ post-SCl. $N=4$ for UN, $N=8$ for $24 \mathrm{~h}$, and $N=6$ for $72 \mathrm{~h}$. One-way ANOVA with Tukey's post hoc test $\left(p=0.004,<0.0001,0.046\right.$, and 0.0001 and $F_{(2,15)}=7.97$, $35.8,3.80$, and 17.7, respectively). $* p<0.05$, *** $<0.01, * * * p<0.001, * * * * p<0.0001$. 

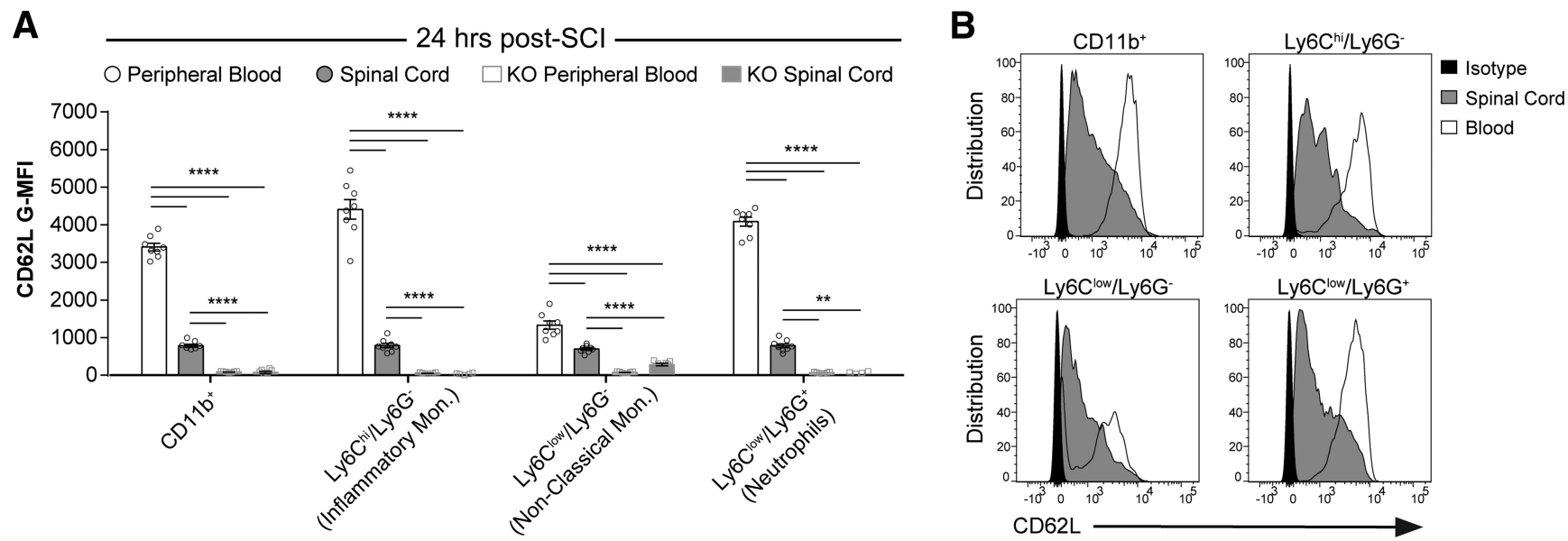

Figure 4. L-selectin is partially shed during infiltration into the spinal cord. $\boldsymbol{A}$, L-selectin levels (G-MFI) on circulating and infiltrated myeloid lineage cells from WT and KO mice at $24 \mathrm{~h}$ post-SCl. Background (isotype) values for CD62L were subtracted from each datapoint so that the $y$-axis represents the specific signal. Autofluorescence resulted in a faint signal in non-classical monocytes in the spinal cord but not in the blood of L-selectin $\mathrm{KO}$ mice. This was likely due to phagocytosed debris. $N=8 / \mathrm{group}$. One-way ANOVA with Tukey's post hoc test $\left(p<0.0001\right.$ for each cell type and $F_{(3,27)}=5.49,7.50,4.71$, and 7.92, respectively). **p $<0.01, * * * * p<$ 0.0001. B, Representative flow cytometry histograms for CD62L staining in leukocyte populations from the blood (white) and spinal cord (gray) of WT mice at $24 \mathrm{~h}$ post-SCl. Representative isotype staining is shown in solid black.

solution (Li et al., 2006). Certain NSAIDs can induce L-selectin shedding in human leukocytes in vitro and in vivo (Díaz-González et al., 1995), which led us to investigate whether an NSAID could be used to down-modulate L-selectin levels on myeloid cells during $\mathrm{SCl}$ and produce benefit. We first performed in vitro experiments to test NSAIDs for their ability to induce L-selectin shedding from murine myeloid cells. We evaluated diclofenac and MFA, which were shown to produce the most L-selectin shedding in human leukocytes (Gómez-Gaviro et al., 2002). Murine granulocytes (predominantly neutrophils), exposed in vitro to either diclofenac or MFA, exhibited a dose-dependent reduction in the level of L-selectin on the cell surface (Fig. $6 A, B$ ).

The in vitro effects of a drug on particular leukocytes do not necessarily predict its in vivo activities with critical factors being the pharmacokinetics of the drug and the turnover and anatomic compartmentalization of leukocytes. To determine whether diclofenac induced the loss of cell surface L-selectin in vivo, uninjured WT mice were administered diclofenac (40 mg/kg, i.p.) and peripheral blood leukocytes were evaluated 2,8 , or $24 \mathrm{~h}$ in separate cohorts of mice for each time point. At $2 \mathrm{~h}$ post-injection, increased L-selectin was detected on peripheral blood CD11 $\mathrm{b}^{+}$cells from diclofenac-treated mice compared to saline-treated mice $(32.2 \%$ increase, $p=0.03$; Fig. $6 C)$, possibly due to mobilization of myeloid cells from the bone marrow. At $8 \mathrm{~h}$ post-injection, there was a $38.3 \%$ reduction of L-selectin on $\mathrm{Ly}_{6 \mathrm{C}} \mathrm{C}^{\text {low }} / \mathrm{Ly} 6 \mathrm{G}^{+}$cells $(p=$ 0.0006 ; Fig. $6 D)$ and a reduction of $26.3 \%$ at $24 \mathrm{~h}(p=$ 0.002; Fig. 6E).

\section{Diclofenac improves long-term functional recovery}

Having verified that diclofenac down-modulates Lselectin levels on myeloid cells in vitro and in vivo, we asked whether this drug could promote long-term recovery after SCl. Mice were treated with a single dose $(20,30$, or $40 \mathrm{mg} / \mathrm{kg}$ ) of diclofenac or vehicle (PBS) immediately after $\mathrm{SCl}$, and neurologic function was assessed using the BMS open field test. We found considerable improvement in locomotor recovery at the highest dose, but not at the lower doses. Enhanced recovery was apparent by $7 \mathrm{~d}$ post-SCl and persisted throughout the remainder of the testing period (Fig. 7A). A subsequent secondary analysis revealed that by day $35,61.5 \%$ of WT mice treated with $40 \mathrm{mg} / \mathrm{kg}$ diclofenac were occasionally stepping as opposed to $0.0 \%$ of PBS-treated mice $(p=0.002$; Fig. $7 B$ ).

Diclofenac as an NSAID with a multiplicity of antiinflammatory activities (Scholer et al., 1986) could provide benefit independently of its effects on L-selectin. To address this issue, we compared neurologic recovery and long-term white matter sparing in L-selectin $\mathrm{KO}$ mice subjected to $\mathrm{SCl}$ and treated with $40 \mathrm{mg} / \mathrm{kg}$ diclofenac or vehicle. As a positive control, we first examined diclofenac in WTs and again observed improved long-term neurologic recovery (Fig. $7 C, D$ ). We then examined diclofenac- and vehicle-treated L-selectin $\mathrm{KO}$ mice and found no differences based on the BMS scale (Fig. 7E). The percentage of spared white matter was also quantified at the lesion epicenter (Fig. 7F,G). Diclofenac-treated WT mice $(40 \mathrm{mg} / \mathrm{kg})$ showed 5 -fold greater white matter sparing compared to PBS-treated WT mice $(p=0.030)$, whereas there was no difference in white matter sparing in KO mice treated with diclofenac versus PBS $(p=0.70)$. Thus, while diclofenac promoted recovery and neuroprotection in spinal cord-injured WTs, it provided no added long-term benefit in the absence of L-selectin.

\section{Diclofenac induces loss of L-selectin from specific leukocyte subsets but does not affect leukocyte accumulation in the injured spinal cord}

We next determined whether diclofenac treatment affected leukocyte accumulation after $\mathrm{SCl}$. A single dose of diclofenac $(40 \mathrm{mg} / \mathrm{kg})$ or vehicle (PBS) was given imme- 
A

Spinal Cord - 24 hrs post-SCl
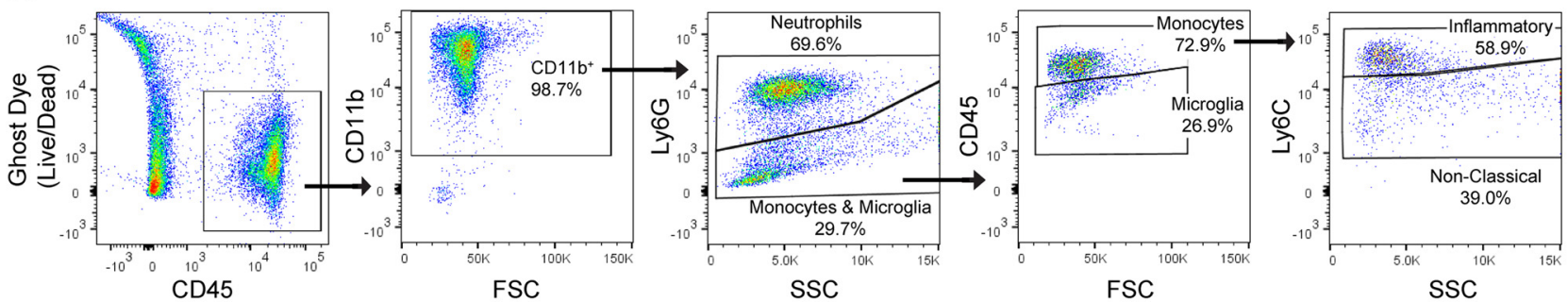

B

Spinal Cord -72 hrs post-SCl
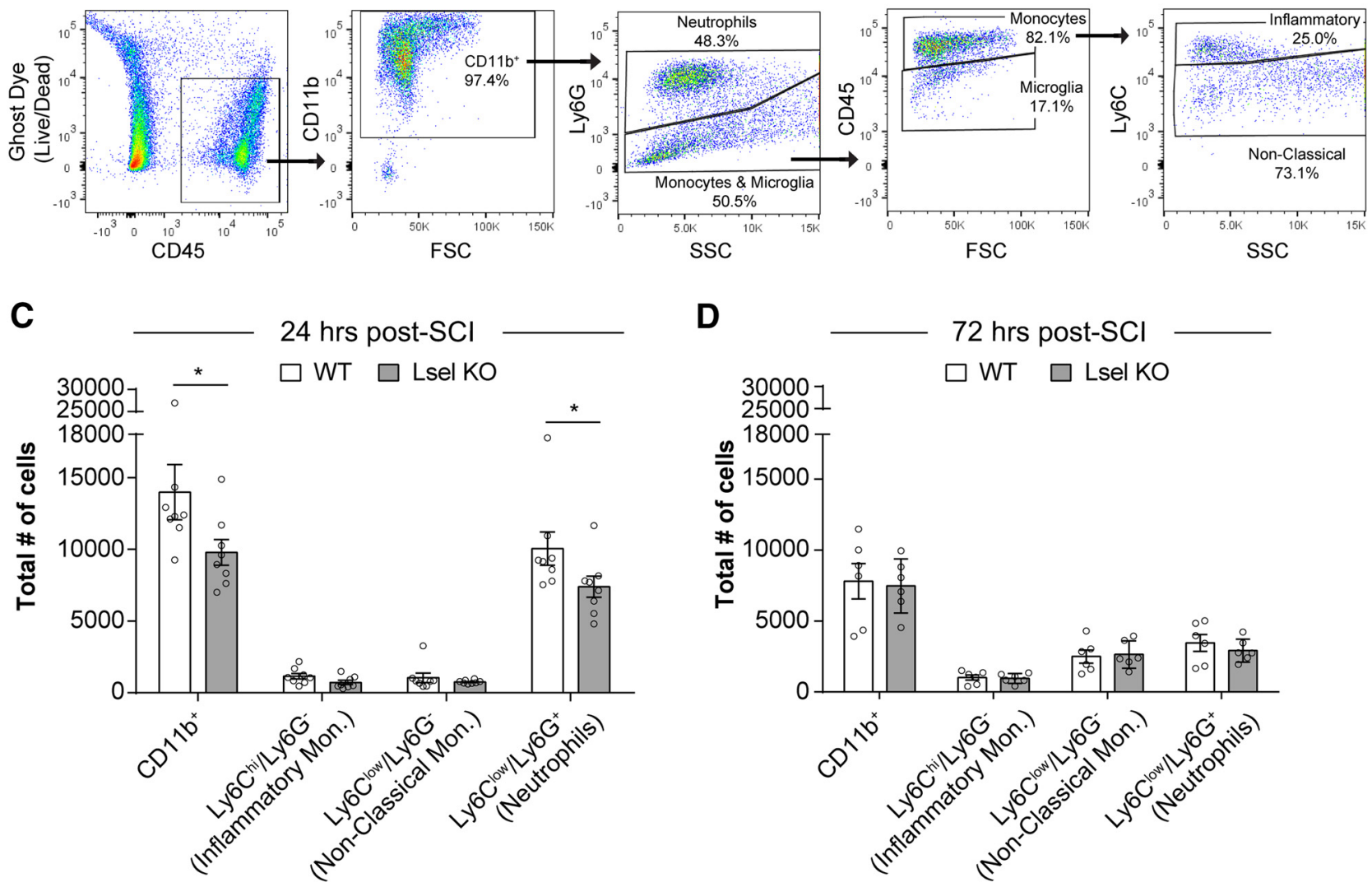

E

$\mathbf{F}$ Microglia (CD11b+CD45 /ow/Ly6G-)
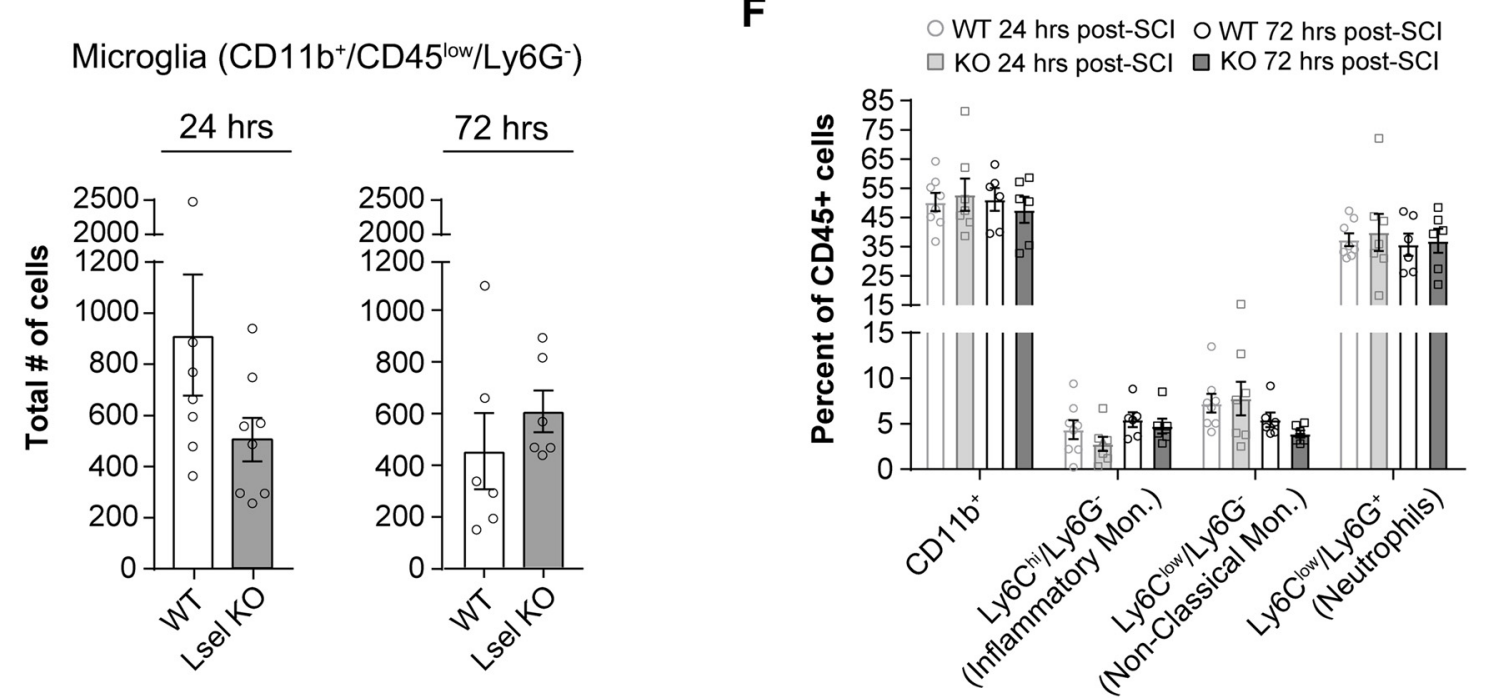

Figure 5. Leukocyte accumulation is transiently reduced in KO mice compared to WT mice after SCl. $\boldsymbol{A}, \boldsymbol{B}$, Flow cytometry gating of 
continued

leukocytes and leukocyte subsets in the injured spinal cord at $\boldsymbol{A}, 24 \mathrm{~h}$ and $\boldsymbol{B}, 72 \mathrm{~h}$ post-SCl. $\boldsymbol{C}$, Accumulation of myeloid cells $\left(\mathrm{CD} 11 \mathrm{~b}^{+}\right)$and neutrophils $\left(\mathrm{Ly} 6 \mathrm{C}^{\text {low }} / \mathrm{Ly} 6 \mathrm{G}^{+}\right)$, as determined by flow cytometry, was reduced in L-selectin KO compared to WT mice at $24 \mathrm{~h}$ post-SCI $\left(* p=0.028\right.$ and 0.038 , respectively). There were no differences in infiltrating inflammatory $\left(\right.$ Ly6 $\left.\mathrm{C}^{\mathrm{hi}} / \mathrm{Ly} 6 \mathrm{GG}^{-}, p=0.10\right)$ or non-classical monocyte subsets (Ly6Clow/Ly6G-, $p=0.72$ ) between WT and KO mice. $N=7$ for WT and $N=8$ for KO.

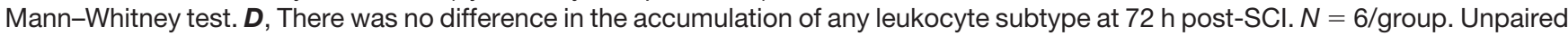
two-tailed Student's $t$ tests. $p=0.82,0.81,0.81$, and 0.45 and $t_{(10)}=0.23,0.25,0.24$, and 0.79 , respectively. $\boldsymbol{E}$, There were no differences in microglia $\left(\mathrm{CD} 11 \mathrm{~b}^{+} / \mathrm{CD} 45^{\text {low }} / \mathrm{Ly} 6 \mathrm{G}^{-}\right)$between WT and KO mice at 24 or $72 \mathrm{~h}$ post-SCI $(p=0.10$ and 0.38 , respectively). $\boldsymbol{F}$, Prevalence of myeloid lineage subsets in the peripheral blood was similar between WT and KO mice at 24 and $72 \mathrm{~h}$ post-SCl. $N=7-8 /$ genotype. Unpaired two-tailed Student's $t$ tests. No differences were detected $\left(p=0.68,0.25,0.80\right.$, and 0.70 and $t_{(13)}=$ $0.42,1.19,0.25$, and 0.40 , respectively).

diately after SCl in WT mice. Peripheral blood and spinal cords were harvested $24 \mathrm{~h}$ later, and flow cytometry was performed to determine the levels of L-selectin as well as the accumulation of leukocyte subsets in the cord (Fig. $8 A)$. Peripheral blood was also acquired from uninjured WT mice to compare basal expression levels of $L$-selectin in circulating myeloid lineages. Consistent with the results above (Fig. $3 B$ ), at $24 \mathrm{~h}$ post-SCl, injury itself (with saline injection) resulted in over 2-fold greater levels of
L-selectin on Ly6Chi/Ly6G- cells $(p=0.005$; Fig. $8 B, D)$ in blood. At $24 \mathrm{~h}$ post-SCl, diclofenac reduced $\mathrm{L}$-selectin on CD $11 b^{+}$cells $(38.2 \%$ reduction, $p=0.004)$, Ly6Clow/ Ly6G ${ }^{-}$cells $(34.6 \%$ reduction, $p=0.022)$, and Ly6Clow/ Ly6G ${ }^{+}$cells $(41.1 \%$ reduction, $p=0.005)$, but not on Ly6C ${ }^{\text {hi }} /$ Ly6G $G^{-}$cells $(p=0.12)$ in blood of injured mice compared to vehicle-treated controls (Fig. 8B,D). Importantly, diclofenac did not activate myeloid cells in the blood ( $24 \mathrm{~h}$ post-SCl), as reflected by no change in

\section{A}
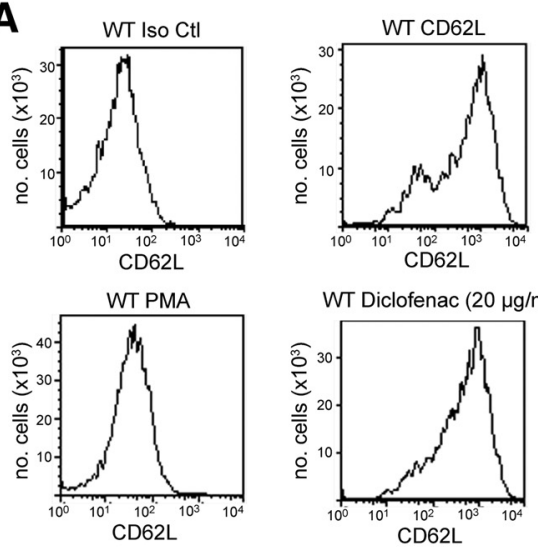

WT Diclofenac $(20 \mu \mathrm{g} / \mathrm{m})$

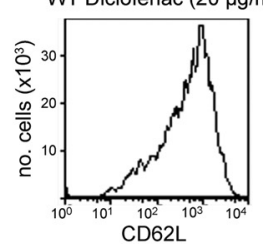

C

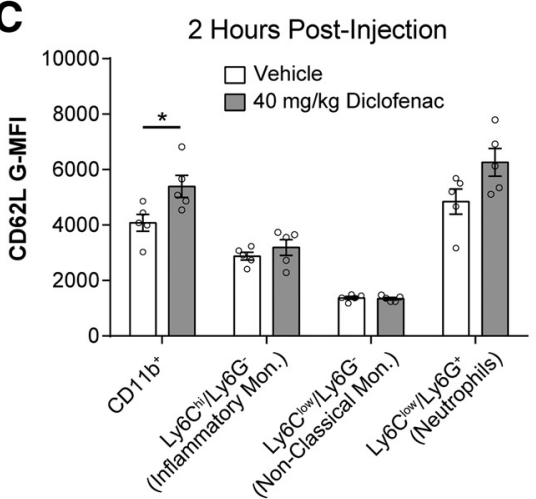

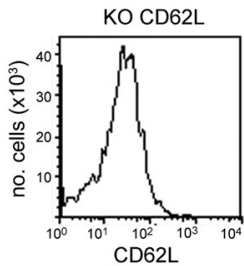

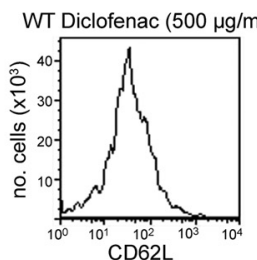

B

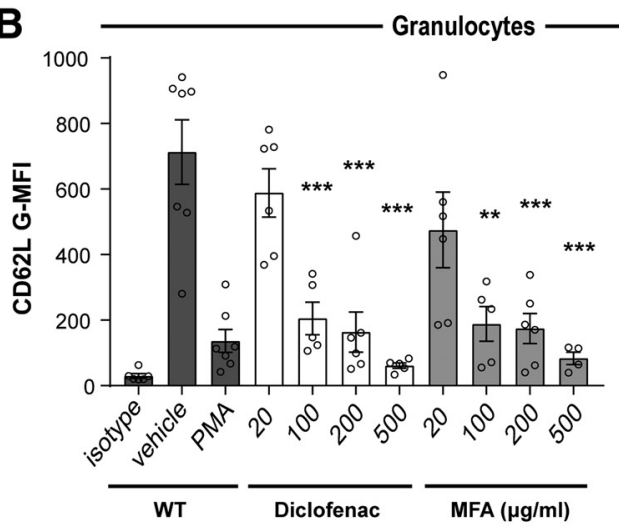

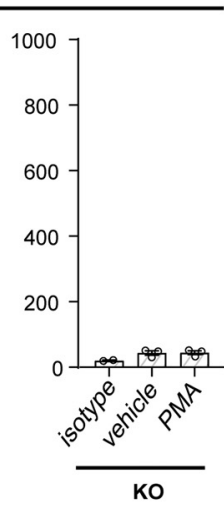

D

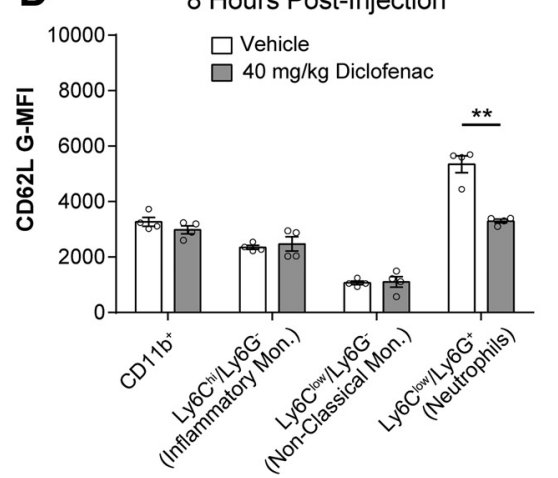

E 24 Hours Post-Injection

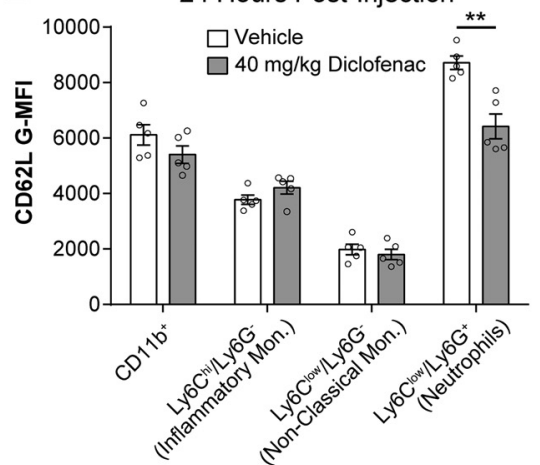

Figure 6. NSAIDs induce L-selectin shedding. $\boldsymbol{A}$, CD62L flow cytometry histograms for WT or L-selectin KO granulocytes treated with PMA or diclofenac (20 or $500 \mu \mathrm{g} / \mathrm{ml}$ ) and stained with an isotype control antibody (Iso Ctl) or a CD62L antibody. B, CD62L expression (G-MFI) on WT murine granulocytes was reduced relative to vehicle $(N=7)$ by treatment with diclofenac $(N=5-6)$ and MFA $(N=$ 4-6). $N=3$ /group for KOs. Data were obtained from seven independent experiments. Cells were pooled from three mice for each experiment (21 total mice). One-way ANOVA with Dunnett's post hoc test. For diclofenac, $p<0.0001$ and $F_{(4,24)}=16.2$. For MFA, $p<0.0001$ and $F_{(4,23)}=10.0$. $* p<0.05, * * p<0.01, * * * p<0.001$. C-E, CD62L expression (G-MFI) was reduced on neutrophils $\left(\mathrm{Ly} 6 \mathrm{C}^{\text {low }} / \mathrm{Ly}_{6 \mathrm{G}} \mathrm{G}^{+}\right)$in uninjured mice receiving diclofenac relative to vehicle control at 8 and $24 \mathrm{~h}$ after injection. $N=4 / \mathrm{group}$ at $8 \mathrm{~h}$ and $N=5$ /group at 2 and $24 \mathrm{~h}$. Unpaired two-tailed Student's $t$ tests. $* p=0.031,0.0006$, and 0.002 , and $t_{(8)}=2.61, t_{(6)}=6.64$, and $t_{(8)}=4.52$, respectively. 


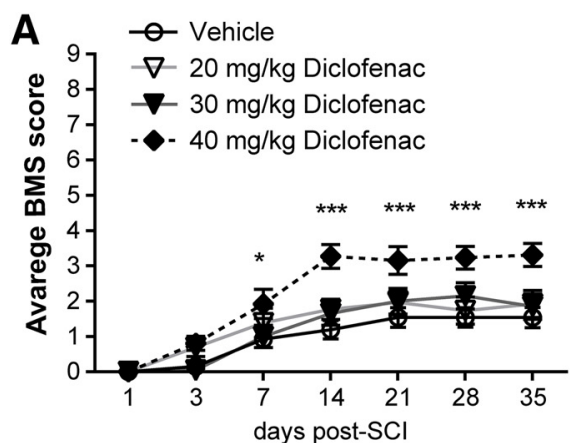

C
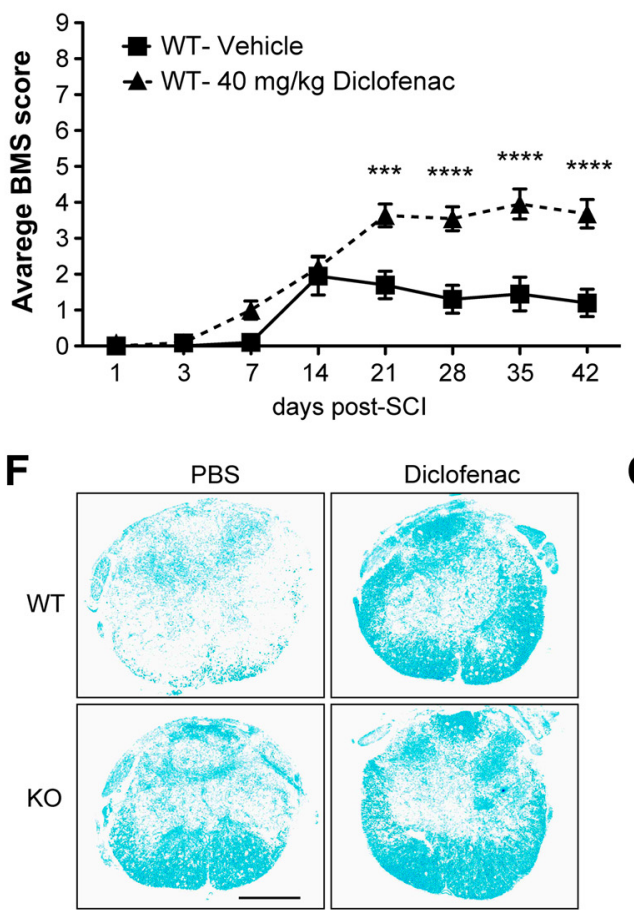

B
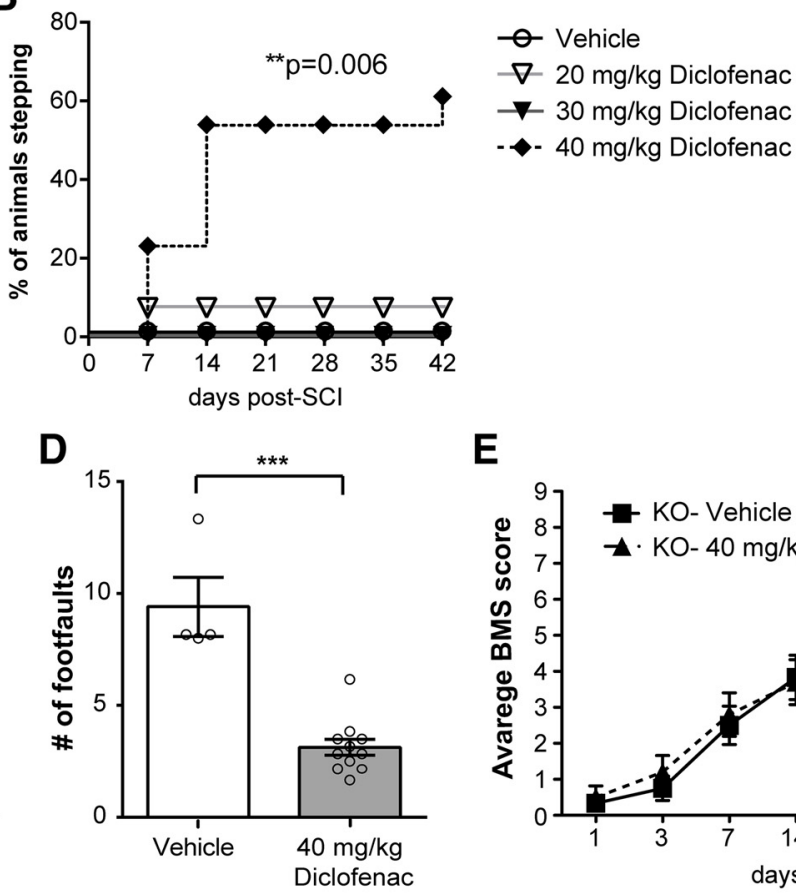

E

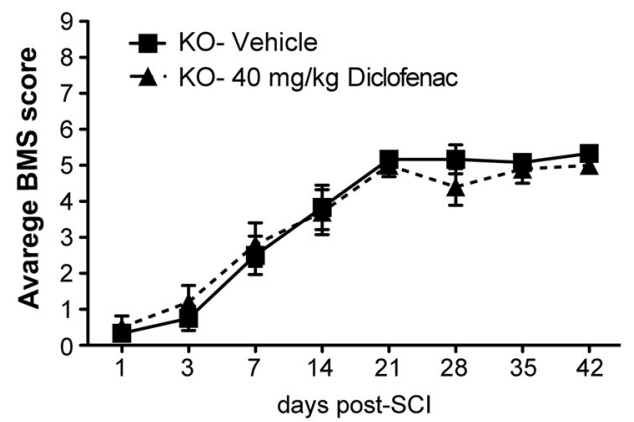

G

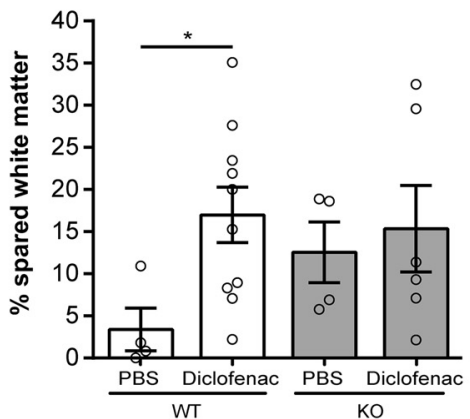

Figure 7. Long-term functional recovery and white matter sparing are improved in spinal cord-injured WT mice treated with diclofenac immediately after injury. $\boldsymbol{A}$, Spinal cord-injured mice treated with $40 \mathrm{mg} / \mathrm{kg}$ diclofenac showed improved recovery starting at $7 \mathrm{~d}$ post-SCl as determined by the BMS open field test. $N=10$ for $30 \mathrm{mg} / \mathrm{kg}$ diclofenac, and $N=13$ for all other groups. Repeated measures two-way ANOVA with Tukey's post hoc test (interaction $p<0.001$; time $p<0.001$; treatment $p=0.003$ and $F_{(3,45)}=5.50$ ). $* * * p<0.0001$ for vehicle versus $40 \mathrm{mg} / \mathrm{kg}$ diclofenac. No differences were observed between vehicle and $20 \mathrm{or} 30 \mathrm{mg} / \mathrm{kg}$ diclofenac. $\boldsymbol{B}$, Stepping was improved in $40 \mathrm{mg} / \mathrm{kg}$ diclofenac-treated mice compared to mice receiving vehicle control. $N=10$ for $30 \mathrm{mg} / \mathrm{kg}$ diclofenac, and $N=13$ for all other groups. $\chi^{2}$ analysis followed by a one-sided Fisher's exact test. $* * p=0.006$ for vehicle versus $40 \mathrm{mg} / \mathrm{kg} . p=0.006$ for 20 versus $40 \mathrm{mg} / \mathrm{kg}$ and $p=0.003$ for 30 versus $40 \mathrm{mg} / \mathrm{kg}$. C, Spinal cord-injured WT mice treated with 40 $\mathrm{mg} / \mathrm{kg}$ diclofenac showed improved recovery compared to vehicle controls. $N=10$ for vehicle and $N=11$ for diclofenac. Repeated measures two-way ANOVA with Sidak's post hoc test (interaction $p<0.001$, time $p<0.0001$, treatment $p=0.0004$, and $F_{(1,19)}=$ 18.8). $* * * p<0.001, * * * * p<0.0001$. $\boldsymbol{D}$, The number of foot faults was reduced in diclofenac-treated mice. $N=4$ for PBS and $N=$ 11 for diclofenac. Mann-Whitney test. $* * * p=0.0007$. E. Functional recovery was similar between L-selectin KO mice treated with diclofenac or vehicle (PBS). $N=6$ for PBS and $N=5$ for diclofenac. Repeated measures two-way ANOVA (interaction $p=0.54$, time $p<0.0001$, treatment $p=0.85$ and $\left.F_{(1,9)}=0.04\right)$. $\boldsymbol{F}$, Representative images of the lesion epicenter, stained with LFB, in mice treated with vehicle (PBS) or diclofenac. Scale bar $=500 \mu \mathrm{m}$. G, Spared white matter was increased in WT mice, but not L-selectin KO mice, treated with diclofenac compared to vehicle (PBS) at $42 \mathrm{~d}$ post-SCI. Data are expressed as proportional area. $N=4$ for PBS-WT, $N$ $=10$ for diclofenac-WT, $N=4$ for PBS-KO, and $N=6$ for diclofenac-KO. Unpaired two-tailed Student's $t$ test. $* p=0.030$ and $t_{(12)}$ $=2.46$. For $\mathrm{KO}, p=0.70$ and $t_{(8)}=0.40$.

CD11b levels (Fig. 8E). Thus, the actions of diclofenac do not appear to be attributable to a generalized activation of these cells.

No differences were apparent in the total numbers of CD11 $b^{+}$cells or myeloid lineage subsets in the spinal cords of diclofenac-treated mice at $24 \mathrm{~h}$ post-SCl com- pared to mice receiving the vehicle control (Fig. 8F). However, diclofenac reduced the level of L-selectin on infiltrated $\mathrm{CD}_{11} \mathrm{~b}^{+}$cells $(26.7 \%$ loss, $p=0.020$; Fig. $8 C, G)$, Ly6C low/Ly6G- cells (28.8\% loss, $p=0.008)$, and Ly6C low/Ly6G ${ }^{+}$cells (31.8\% loss, $\left.p=0.049\right)$. There was no effect on Ly6C ${ }^{\text {hi }} /$ Ly6G $G^{-}$cells $(p=0.59)$. Thus, while 
A
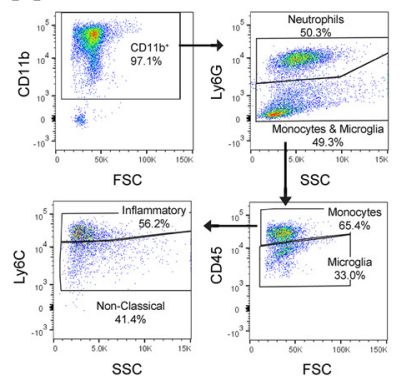

D - Peripheral Blood (24 hrs post-SCl) -
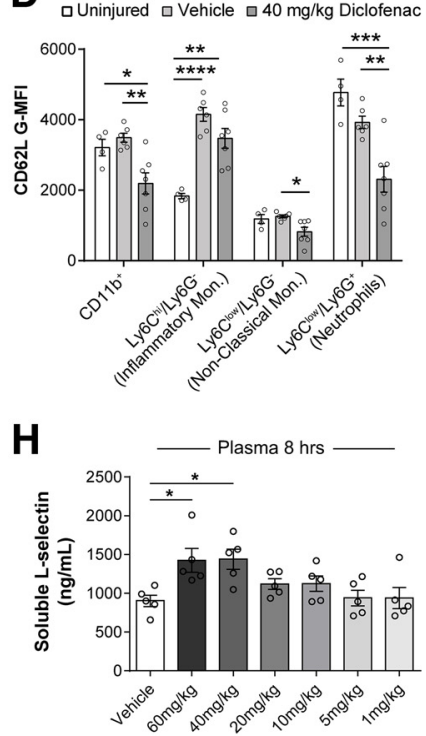

B

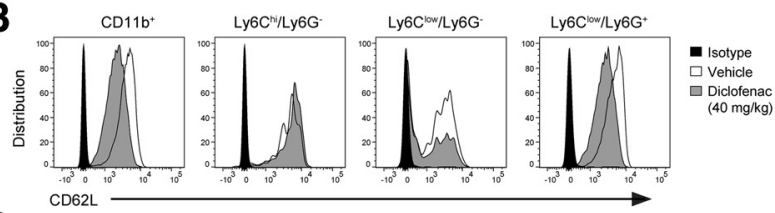

C
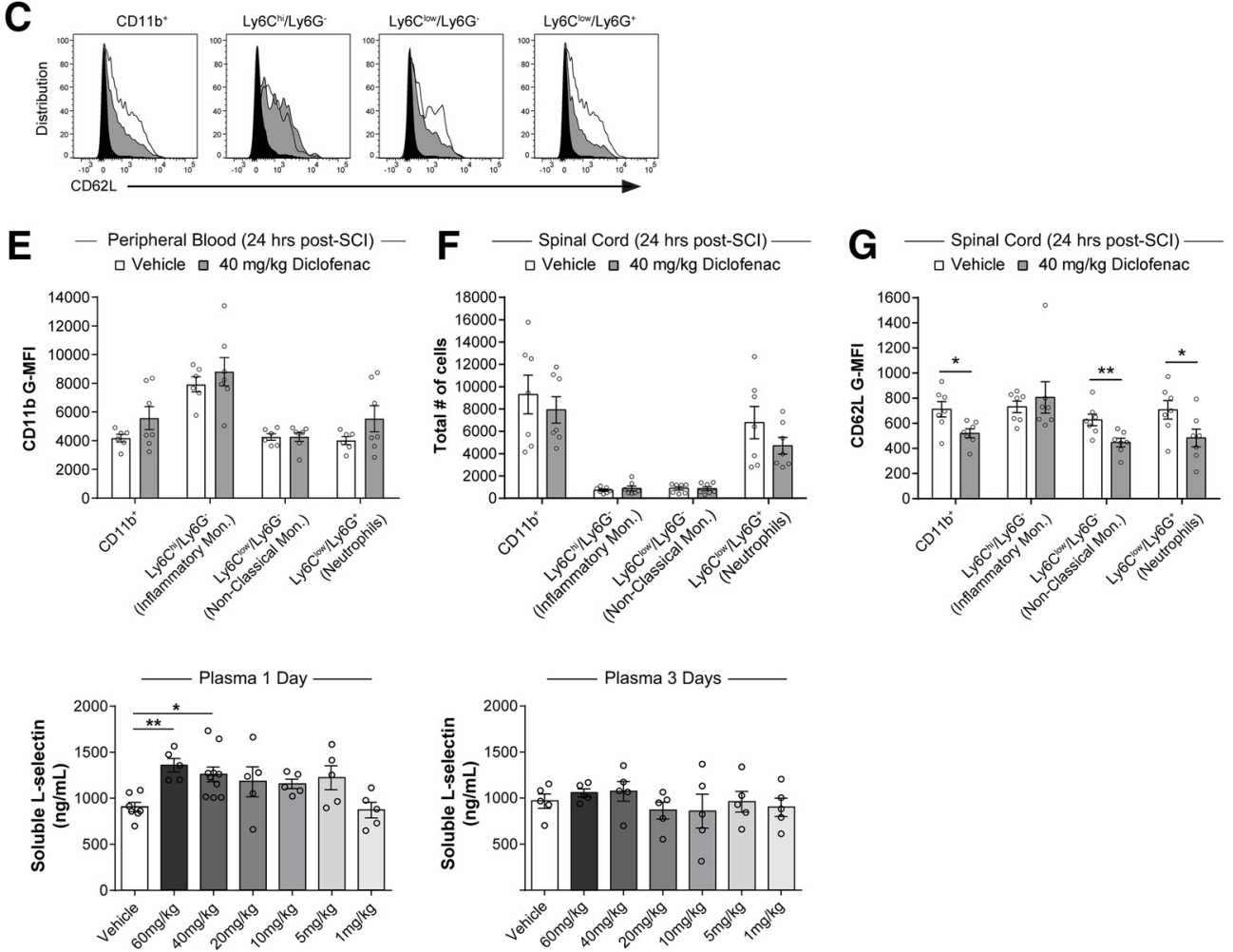

Figure 8. Diclofenac treatment reduces L-selectin on peripheral blood and infiltrated leukocytes but does not alter accumulation in the injured spinal cord. $\boldsymbol{A}$, Flow cytometry gating for infiltrated myeloid cells and myeloid subsets. $\boldsymbol{B}, \boldsymbol{C}$, Representative flow cytometry histograms for CD62L staining in leukocyte populations from the blood $(\boldsymbol{B})$ or spinal cord (C) of vehicle-treated (white) and diclofenac-treated (gray) mice at $24 \mathrm{~h}$ post-SCl. Representative isotype staining is shown in black. $\boldsymbol{D}$, Flow cytometry analysis for CD62L expression on peripheral blood leukocytes from uninjured mice and injured mice treated with diclofenac or vehicle (PBS). Diclofenac induced a reduction of L-selectin on neutrophils and non-classical monocytes $(p=0.005$ and 0.02 , respectively). $N=$ 4/uninjured and $N=6-7 / \mathrm{SCl} /$ treatment. One-way ANOVA with Tukey's post hoc test $(p=0.004,<0.0001,0.019$, and 0.0004 and $F_{(2,14)}=8.47,20.3,5.30$, and 14.8, respectively). $* p<0.05, * * p<0.01, * * * p<0.001$. E. Flow cytometry analysis for CD11b levels on peripheral blood leukocytes from spinal cord-injured mice treated with diclofenac or vehicle (PBS). There were no differences in CD11b levels on myeloid cells or myeloid lineage subsets. $N=6-7 /$ treatment. Unpaired two-tailed Student's $t$ tests. $p=0.15$, 0.47 , 0.99 , and 0.16 and $t_{(11)}=1.5,0.75,0.01$, and 1.5 , respectively. $\boldsymbol{F}$, There were no differences in the accumulation of total myeloid cells $\left(\mathrm{CD} 11 \mathrm{~b}^{+}\right)$or any myeloid lineage subset in spinal cords of diclofenac-treated mice compared to vehicle-treated mice at $24 \mathrm{~h}$ post-SCl. $N=7$ /treatment. Unpaired two-tailed Student's $t$ tests. $p=0.37,0.53,0.92$, and 0.23 and $t_{(12)}=0.66,0.64,0.12$, and 1.27 , respectively. G, Flow cytometry analysis demonstrated loss of L-selectin on total leukocytes $\left(\right.$ CD $45^{+}, p=0.020$ and $\left.t_{(12)}=2.67\right)$, total myeloid cells $\left(\mathrm{CD} 11 \mathrm{~b}^{+}, * p=0.020\right.$ and $\left.t_{(12)}=2.69\right)$, non-classical monocytes (Ly6C ${ }^{\text {low }} / \mathrm{Ly} 6 \mathrm{G}^{-}, * * p=0.008$ and $\left.t_{(12)}=3.16\right)$, and neutrophils $\left(\mathrm{Ly} 6 \mathrm{C}^{\text {low }} / \mathrm{Ly}_{6 \mathrm{G}}{ }^{+}, * p=0.049\right.$ and $\left.t_{(12)}=2.20\right)$ in the spinal cord of diclofenac-treated versus vehicle-treated mice at 24 $\mathrm{h}$ post-SCl. There was no effect on L-selectin on inflammatory monocytes (Ly6Chi/Ly6G-, $p=0.59$ and $\left.t_{(12)}=0.56\right)$. $N=7 /$ treatment. Unpaired two-tailed Student's $t$ tests. $\boldsymbol{H}$, ELISA for sL-selectin in the peripheral blood at 8,24 , and $72 \mathrm{~h}$ post-SCI in mice receiving a vehicle (PBS) control injection or $1-60 \mathrm{mg} / \mathrm{kg}$ of diclofenac. Increased sL-selectin was observed at 8 and $24 \mathrm{~h}$, but not $72 \mathrm{~h}$, post-SCl in mice receiving 40 and $60 \mathrm{mg} / \mathrm{kg}$ diclofenac. $N=5 /$ group for 8 and $72 \mathrm{~h} ; N=5 /$ group at $24 \mathrm{~h}$ except for vehicle $(N=7)$ and $40 \mathrm{mg} / \mathrm{kg}$ diclofenac $(N=10)$. One-way ANOVA followed by Dunnett's post hoc test $\left(p=0.005,0.006\right.$, and 0.71 and $F_{(6,28)}=$ $4.05, F_{(6,35)}=3.72$, and $F_{(6,28)}=0.63$, respectively). $* p<0.05$, **p $<0.01$.

diclofenac did not alter leukocyte accumulation in the injured cord, L-selectin was reduced on the same myeloid populations (i.e., neutrophils and non-classical monocytes) in both the blood and spinal cord of injured animals. To substantiate that diclofenac treatment resulted in shedding of L-selectin from leukocytes, we measured SL-selectin in blood plasma by ELISA. We employed a single dose of diclofenac at increasing doses $(1,5,10,20,40$, and $60 \mathrm{mg} / \mathrm{kg})$ immediately following $\mathrm{SCl}$. Elevated sL-selectin (above vehicle background) was detected at 8 and 24 h post-SCl with 40 and $60 \mathrm{mg} / \mathrm{kg}$ of diclofenac but not at the lower doses (Fig. 8H). The elevation did not persist at $72 \mathrm{~h}$ post-injection. Importantly, the high concentration of 

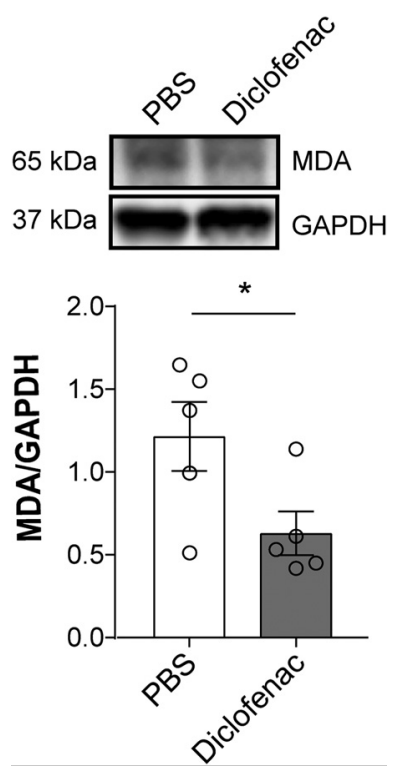

Figure 9. Diclofenac treatment reduces acute oxidative stress at $72 \mathrm{~h}$ post-SCl. By immunoblotting, MDA was reduced by $48.1 \%$ in diclofenac-treated versus vehicle-treated WT mice after SCI $\left(* p=0.045, t_{(8)}=2.37\right) . N=5 /$ treatment. Unpaired two-tailed Student's $t$ test. All values were normalized to GAPDH.

diclofenac required to induce L-selectin shedding paralleled the high concentration required to improve longterm neurologic recovery (Fig. $7 A$ ).

\section{Diclofenac reduces acute oxidative stress after $\mathrm{SCl}$}

Antibody-induced ligation of L-selectin has been shown to induce or potentiate the production of ROS by neutrophils (Crockett-Torabi et al., 1995). Therefore, the reduced level of L-selectin on these cells following diclofenac treatment could potentially mitigate oxidative stress in the acutely injured spinal cord. We therefore examined MDA levels in the injured spinal cord at $72 \mathrm{~h}$ post-SCl in mice receiving diclofenac $(40 \mathrm{mg} / \mathrm{kg})$ or vehicle (PBS) immediately following $\mathrm{SCl}$. There was a $48.1 \%$ reduction in MDA between diclofenac and vehicle-treated mice $(p=0.045$; Fig. 9).

\section{Diclofenac improves recovery when delivered within $3 \mathrm{~h}$ after $\mathrm{SCl}$}

To determine the window for the beneficial effects of diclofenac, a single dose of diclofenac $(40 \mathrm{mg} / \mathrm{kg}$, i.p.) was administered at 0,3 , or $8 \mathrm{~h}$ following SCl. Again, we found that immediate delivery of diclofenac improved long-term neurologic recovery of hindlimb function, as seen by greater BMS scores within the first $7 \mathrm{~d}$ post-SCI compared to vehicle-treated mice (Fig. 10A). Stepping was also improved with $66.7 \%$ of diclofenac-treated mice stepping at $42 \mathrm{~d}$ post-SCl compared to $7.7 \%$ of vehicletreated mice $(p=0.003$; Fig. 10D). When administration of diclofenac was delayed for $3 \mathrm{~h}$, improved neurologic recovery was evident starting at $7 \mathrm{~d}$ post-SCl compared to timematched vehicle control mice (Fig. 10B). Although stepping was not improved $(38.5 \%$ vs $18.2 \%, p=0.26$; Fig. $10 E$; Table 2), white matter sparing was 2.3-fold greater in mice receiving diclofenac at $3 \mathrm{~h}$ post-SCl compared to vehicle- treated mice ( $p=0.011$; Fig. $10 G)$. There was no long-term benefit in BMS scores or stepping when diclofenac treatment was delayed to $8 \mathrm{~h}$ post-SCl (Fig. 10C,F).

To determine whether multiple doses of diclofenac conferred additional benefit, we randomly grouped mice into three cohorts and delivered diclofenac $(40 \mathrm{mg} / \mathrm{kg})$ at $0 \mathrm{~h}$ (single dose), 0 and $24 \mathrm{~h}$ (two doses), or 0,24 , and $48 \mathrm{~h}$ (three doses) post-SCl. Long-term neurologic benefit was observed in the single and two-dose groups with improved BMS scores starting at $7 \mathrm{~d}$ post-SCl compared to the vehicle-treated group (Fig. 10H). No additional benefit was observed for two doses compared to a single dose of diclofenac. BMS scores could not be determined for mice receiving three doses of diclofenac due to a high rate of morbidity and mortality. While a single dose of diclofenac exhibited a similar mortality rate to vehicle control injections, there was increased mortality for the double and triple dose regimens (Fig. 10).

\section{Discussion}

The mechanisms underlying secondary pathogenesis, including the pathogenic activities of myeloid cells, after $\mathrm{SCl}$ are not fully understood, thereby limiting the development of clinical therapies. This is the first study to demonstrate the involvement of L-selectin in acute secondary pathogenesis in a murine model of $\mathrm{SCl}$. We show that the genetic ablation of L-selectin markedly improves long-term neurologic recovery and white matter sparing. Pursuing a pharmacologic approach to reduce L-selectin, we demonstrate that the NSAID, diclofenac, induces partial L-selectin shedding from mouse myeloid cells in vivo and improves long-term neurologic outcomes when administered up to $3 \mathrm{~h}$ following injury. Our findings provide support for L-selectin shedding and the subsequent reduction of L-selectin-dependent activities other than myeloid cell recruitment, as an important anti-inflammatory activity of diclofenac during SCl.

Past studies have achieved success in limiting inflammation and secondary damage by targeting specific adhesion molecules (such as P-selectin, CD11d/CD18, and ICAM-1) and chemoattractants/chemokines involved in the migration of peripheral leukocytes into the spinal cord (Hamada et al., 1996; Taoka et al., 1997; Gonzalez et al., 2003; Gris et al., 2004; Popovich and Longbrake, 2008; Saiwai et al., 2010). In the present study, we have investigated L-selectin, which heretofore has not been considered in the context of SCl. A substantial body of evidence has established that L-selectin functions as adhesion/ signaling molecule on myeloid cells and participates in their recruitment and activation at inflammatory sites (Lewinsohn et al., 1987; Pizcueta and Luscinskas, 1994; Tedder et al., 1995; Stadtmann et al., 2013; Zuchtriegel et al., 2015). We found considerable L-selectin levels on all circulating myeloid cell subtypes, including neutrophils and monocytes, in uninjured WT mice. After SCl, L-selectin was dynamically regulated on myeloid cells in blood. Notably, there was a $25.3 \%$ reduction of L-selectin on neutrophils $24 \mathrm{~h}$ after $\mathrm{SCl}$, which may reflect a negative feedback mechanism to attenuate L-selectin-dependent inflammatory activities, as has been described in another 
A

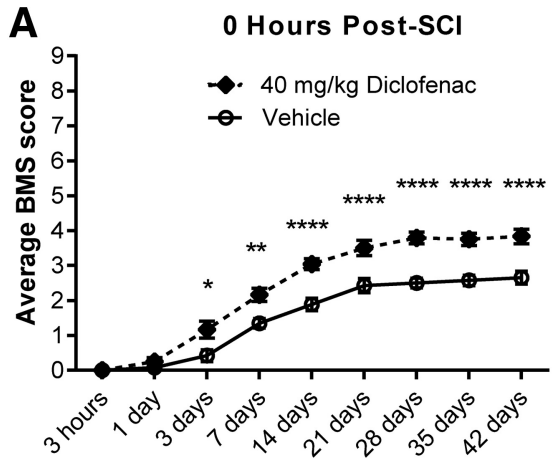

time post-SCI

D

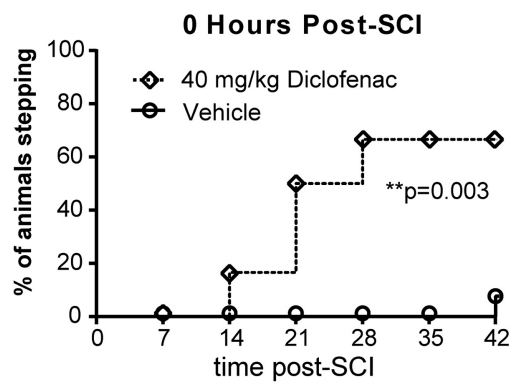

G

Estimated White Matter at Epicenter

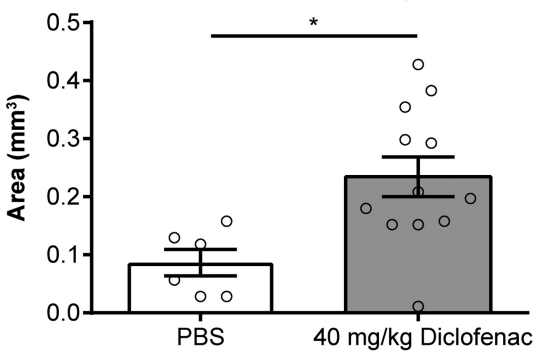

B

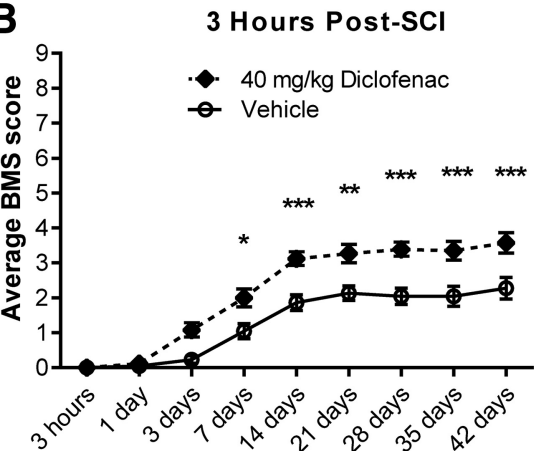

time post-SCI

E

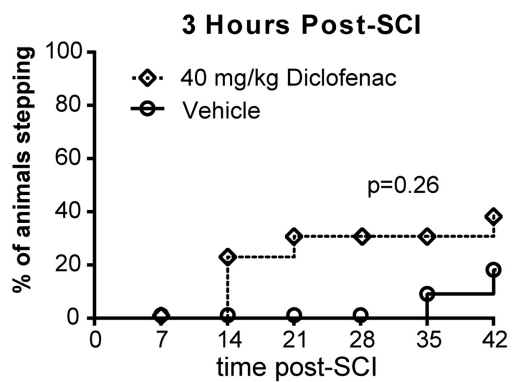

H

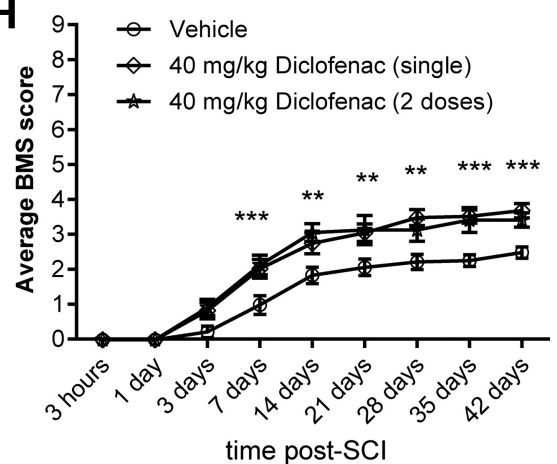

C 8 Hours Post-SCI

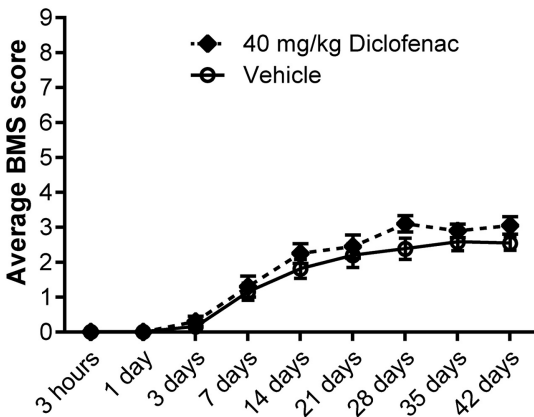

time post-SCl

$\mathbf{F}$

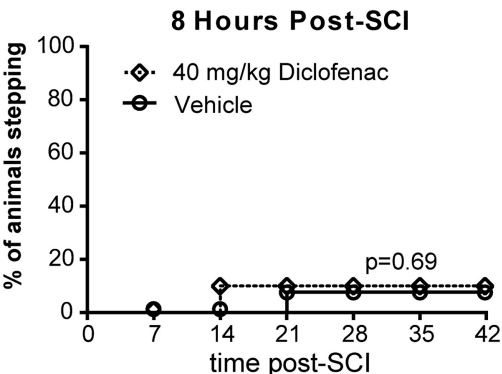

I

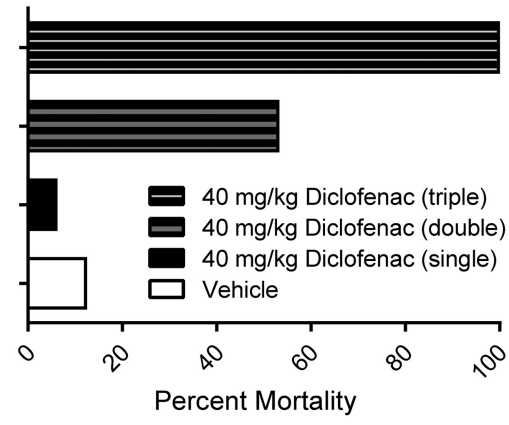

Figure 10. Diclofenac treatment improves long-term recovery when delayed for $3 \mathrm{~h}$, but not $8 \mathrm{~h}$, post-SCl. $\boldsymbol{A}$, BMS scores demonstrated improved neurologic recovery when diclofenac was delivered immediately following injury. $N=13$ for vehicle and $N$ $=12$ for diclofenac. Two-way ANOVA with Sidak's post hoc test (interaction $p<0.0001$, time $p<0.0001$, treatment $p<0.0001$ and $\left.F_{(1,23)}=26.0\right) . * p<0.05, * * p<0.01$, ***p $<0.001$, ****p $<0.0001$. $\boldsymbol{B}$, Recovery was also improved when administration of diclofenac was delayed to $3 \mathrm{~h}$ post-SCI. $N=11$ for vehicle and $N=13$ for diclofenac. Two-way ANOVA with Sidak's post hoc test (interaction $p<0.0001$, time $p<0.0001$, treatment $p=0.0005$ and $F_{(1,22)}=17.0$ ). $* p<0.05$, $* * p<0.01$, ***p $<0.001$. $\boldsymbol{C}$, No improvement was observed when diclofenac was delayed to $8 \mathrm{~h}$ post-SCl. $N=13$ for vehicle and $N=10$ for diclofenac. Two-way ANOVA with Sidak's post hoc test (interaction $p=0.42$, time $p<0.001$, treatment $p=0.23$ and $F_{(1,21)}=1.51$ ). $\boldsymbol{D}$, Improved stepping ability was observed when diclofenac was delivered immediately after injury. $\chi^{2}$ analysis followed by a one-sided Fisher's exact test. $N=13$ for vehicle and $N=12$ for diclofenac. $* * p=0.003$. $E$, No benefit for stepping was observed when diclofenac was delivered $3 \mathrm{~h}$ after injury. $\chi^{2}$ analysis followed by a one-sided Fisher's exact test. $N=11$ for vehicle and $N=13$ for diclofenac. $* p=0.26$. $\boldsymbol{F}$, No benefit for stepping was observed with an 8-h delay of diclofenac administration. $\chi^{2}$ analysis followed by a one-sided Fisher's exact test. $N=13$ for vehicle and $N=10$ for diclofenac. $p=0.69$. G, Spared white matter at the lesion epicenter was increased at $42 \mathrm{~d}$ post-SCI in WT mice treated with diclofenac at $3 \mathrm{~h}$ post-SCl compared to the time-matched vehicle (PBS) control group. Data are expressed as total area. $N=6$ for PBS and $N=12$ for diclofenac. Two-tailed Student's $t$ test. $* p=0.011, t_{(16)}=2.87$. $\boldsymbol{H}$, No additional benefit in BMS score was achieved by administering a second dose of diclofenac. $N=13$ for vehicle, $N=15$ for single dose, and $N=7$ for two doses. Two-way ANOVA with Tukey's post hoc test (interaction $p<0.001$, time $p<0.001$, treatment $p=$ 0.002 and $\left.F_{(2,32)}=8.04\right) . p>0.55$ for single versus two doses for all timepoints. $* p<0.05, * * p<0.01, * * * p<0.001$. $I$, Multiple doses of diclofenac resulted in higher mortality rates.

setting of injury and inflammation (Strausbaugh et al., 1999). Reduced L-selectin has been previously observed in circulating neutrophils in spinal cord-injured human patients (Bao et al., 2008); however, this study also found reduced L-selectin levels on circulating monocytes. The increase in L-selectin on circulating monocyte populations in our study in mouse may reflect species differences in $\mathrm{L}$-selectin regulation during inflammatory responses to $\mathrm{SCl}$. 
Table 2. Categorical analysis of BMS scoring

\begin{tabular}{|c|c|c|c|c|c|c|}
\hline \multirow{3}{*}{$\begin{array}{c}\text { BMS category } \\
0\end{array}$} & \multicolumn{3}{|c|}{ Vehicle (3 h post-SCI, $N=11$ ) } & \multicolumn{3}{|c|}{ Diclofenac (3 h post-SCI, $N=13$ ) } \\
\hline & $1 \mathrm{~d}$ & $7 d$ & $42 d$ & $1 d$ & $7 d$ & $42 \mathrm{~d}$ \\
\hline & $100 \%(11)$ & $27.3 \%(3)$ & & $100 \%(13)$ & $7.7 \%(1)$ & \\
\hline 1 & & $45.5 \%(5)$ & $27.3 \%(3)$ & & $38.5 \%(5)$ & \\
\hline 2 & & $27.3 \%(3)$ & $45.5 \%(5)$ & & $15.4 \%(2)$ & $30.8 \%(4)$ \\
\hline 3 & & & $9.1 \%(1)$ & & $38.5 \%(5)$ & $30.8 \%(4)$ \\
\hline 4 & & & $18.2 \%(2)$ & & & $7.7 \%(1)$ \\
\hline 5 & & & & & & $30.8 \%(4)$ \\
\hline
\end{tabular}

L-selectin deficiency was associated with partially reduced neutrophil accumulation into the acutely injured spinal cord ( $24 \mathrm{~h}$ post-SCl). This is consistent with the participation of L-selectin in recruitment of neutrophils, e.g., as an adhesive molecule in secondary tethering to other leukocytes or as a signaling molecule in activating integrins on neutrophils (Walcheck et al., 1996; Zarbock et al., 2011; Stadtmann et al., 2013; Morikis et al., 2017). At $72 \mathrm{~h}$ post-SCl, when neutrophil numbers in the cord were $\sim 3$-fold fewer than at $24 \mathrm{~h}$ (reflecting death or exit of the infiltrated neutrophils), there was no difference between WT and KO mice. However, at the same time point, we did find reduced oxidative stress in the acutely injured cord of L-selectin KO mice, suggesting the possibility of ROS as a component of L-selectin mediated pathogenesis. Many studies have established a role for L-selectin in modulating the internal signaling and secretome of neutrophils (Zarbock and Ley, 2008), including the potentiation of ROS production (Crockett-Torabi et al., 1995). Elucidation of the signaling pathways by which L-selectin contributes to ROS production after $\mathrm{SCl}$ could identify novel targets to reduce acute secondary pathogenesis.

Myelin sheaths of CNS, but not peripheral nervous system, express ectopic ligands (presumed to be carbohydrate-based and structurally related to true biological ligands) for L-selectin that are sufficient to support leukocyte adhesion in an in vitro assay (Huang et al., 1991; Huang et al., 1994). We found that neutrophils that infiltrated the injured spinal cord at 24 and $72 \mathrm{~h}$ post-SCI retained $19.2 \%$ and $14.8 \%$ of L-selectin levels, respectively, relative to those in peripheral blood. These levels are still appreciable, since L-selectin is normally present at high density on blood leukocytes $\left(\sim 10^{5}\right.$ molecules/cell; Simon et al., 1992). Infiltrating neutrophils and monocytes could potentially interact with these "illegitimate" ligands via L-selectin to facilitate activation of effector functions that promote myelin degradation, a mechanism that has been invoked in a model of experimental allergic encephalitis (Grewal et al., 2001). Notably, engagement of L-selectin on neutrophils with incidental carbohydrate ligands (carcinoma or saliva mucins) potentiates the degranulation of these cells (Shao et al., 2011), even after considerable shedding of L-selectin (Mohanty et al., 2015). Thus, reduced $L$-selectin on spinal cord-infiltrated neutrophils may still be sufficient to drive post-recruitment activities.

NSAIDs are a heterogeneous group of compounds that continue to be an important intervention in patients with non-severe inflammatory disorders. Several NSAIDs provide neuroprotection in experimental models of $\mathrm{SCl}$ (Kwon et al., 2011). In the present study, we show that administration of diclofenac led to marked improvements in long-term recovery and sparing of white matter after $\mathrm{SCl}$. The beneficial effects of diclofenac treatment following $\mathrm{SCl}$ were comparable to those seen in L-selectin $\mathrm{KO}$ mice. Our study thus adds diclofenac, a widely prescribed medication (Altman et al., 2015), to the group of NSAIDs that are beneficial in $\mathrm{SCl}$.

We were initially drawn to diclofenac because it belongs to the subgroup of NSAIDs that are capable of inducing a high level of L-selectin shedding from the surface of leukocytes (Díaz-González et al., 1995; Gómez-Gaviro et al., 2002). In the present study, diclofenac induced the loss of L-selectin in non-classical monocytes and neutrophils within the blood and spinal cord of injured mice. Our report is the first to show a differential effect of NSAIDs on loss of L-selectin from monocyte subtypes with nonclassical monocytes being the susceptible population in the context of SCl. The diclofenac-induced reduction in L-selectin on non-classical monocytes could potentially impact signaling by these cells and diminish their deleterious activities in SCI (Donnelly et al., 2011). With respect to neutrophils, the diclofenac-induced reduction of L-selectin levels was not accompanied by reduced accumulation in the injured spinal cord (24 h), which contrasts with the observations in L-selectin $\mathrm{KO}$ mice at this time point. This difference may be ascribed to the fact that diclofenac treatment resulted in only a partial loss of L-selectin. Nonetheless, the diclofenac treatment reduced oxidative stress at $72 \mathrm{~h}$ post-SCl, an effect that could plausibly be a consequence of reduced signaling and degranulation of neutrophils, as detailed above.

The anti-inflammatory activities of NSAIDs are usually attributed to inhibition of cyclooxygenase (COX), a key enzyme for prostaglandin production. However, SánchezMadrid, Díaz-González, and co-workers have also highlighted L-selectin shedding from neutrophils as a potential anti-inflammatory action of certain NSAIDs (HerreraGarcía et al., 2013; Díaz-González and Sánchez-Madrid, 2015). In our experiments, we cannot exclude that the benefit of diclofenac is due to COX inhibition or diclofenac-induced shedding of molecules other than L-selectin. However, our finding of equivalent neurologic outcomes after $\mathrm{SCl}$ in L-selectin $\mathrm{KO}$ mice, treated with diclofenac compared to the vehicle control group, suggests that the beneficial effect of diclofenac is related to its ability to induce L-selectin shedding. Taken together, our diclofenac findings are consistent with the possibility that the partial loss of L-selectin induced by this drug reduces the deleterious activities of myeloid cells in secondary pathogenesis. Further mechanistic studies are 
needed to substantiate this scenario as opposed to other potential activities of diclofenac.

In our experiments, $40 \mathrm{mg} / \mathrm{kg}$ of diclofenac was required to improve long-term neurologic recovery after $\mathrm{SCl}$, but repeated dosing at this high level was associated with increased mortality. According to the FDA's guidelines for conversion to a human equivalent dose (Nair and Jacob, 2016), the dose for a 60-kg individual would be $3.25 \mathrm{mg} / \mathrm{kg}$. In fact, oral administration of diclofenac to human subjects at a dose of $\sim 2.5 \mathrm{mg} / \mathrm{kg} / \mathrm{d}$ has been shown to promote robust loss of L-selectin on blood neutrophils (Baranda, 1998). Thus, it would be feasible to test diclofenac for efficacy in human $\mathrm{SCl}$ at an FDAapproved dose. Evaluation of diclofenac in the context of sex as a biological variable will be an important factor in such studies.

Our findings establish a therapeutic window for diclofenac administration with efficacy observed up to at least $3 \mathrm{~h}$, but $<8 \mathrm{~h}$, after SCl. This timeframe is consistent with our observations that the pathologic contributions of L-selectin are associated with early myeloid cell activities $(<72 \mathrm{~h}$ post$\mathrm{SCl})$. Recent clinical studies have also highlighted the importance of early intervention with anti-inflammatory strategies (Ahuja et al., 2016). Future exploration of more clinically relevant methods for delivery of diclofenac and development of faster acting structural analogues with improved safety profiles may extend the therapeutic window for strategies targeting L-selectin after SCl.

\section{References}

Ahuja CS, Martin AR, Fehlings M (2016) Recent advances in managing a spinal cord injury secondary to trauma. F1000Res 5 . CrossRef

Altman R, Bosch B, Brune K, Patrignani P, Young C (2015) Advances in NSAID development: evolution of diclofenac products using pharmaceutical technology. Drugs 75:859-877. CrossRef Medline

Azbill RD, Mu X, Bruce-Keller AJ, Mattson MP, Springer JE (1997) Impaired mitochondrial function, oxidative stress and altered antioxidant enzyme activities following traumatic spinal cord injury. Brain Res 765:283-290. Medline

Bao F, Chen Y, Schneider KA, Weaver LC (2008) An integrin inhibiting molecule decreases oxidative damage and improves neurological function after spinal cord injury. Exp Neurol 214:160-167. CrossRef Medline

Baranda L, Abud-Mendoza C, Portales-Perez DP, Layseca E, De La Fuente H, Amaro RG, Ibarra J (1998) In vivo effect on diclofenac potassium L-selectin expression by polymorphonuclear leukocytes. Mex J Rheumatol 13:144-150.

Bareyre FM, Schwab ME (2003) Inflammation, degeneration and regeneration in the injured spinal cord: insights from DNA microarrays. Trends Neurosci 26:555-563. CrossRef Medline

Basso DM, Fisher LC, Anderson AJ, Jakeman LB, McTigue DM, Popovich PG (2006) Basso Mouse Scale for locomotion detects differences in recovery after spinal cord injury in five common mouse strains. J Neurotrauma 23:635-659. CrossRef Medline

Beck KD, Nguyen HX, Galvan MD, Salazar DL, Woodruff TM, Anderson AJ (2010) Quantitative analysis of cellular inflammation after traumatic spinal cord injury: evidence for a multiphasic inflammatory response in the acute to chronic environment. Brain 133:433447. CrossRef Medline

Chatzipanteli K, Garcia R, Marcillo AE, Loor KE, Kraydieh S, Dietrich WD (2002) Temporal and segmental distribution of constitutive and inducible nitric oxide synthases after traumatic spinal cord injury: effect of aminoguanidine treatment. J Neurotrauma 19:639-651. CrossRef
Crockett-Torabi E, Sulenbarger B, Smith CW, Fantone JC (1995) Activation of human neutrophils through L-selectin and Mac-1 molecules. J Immunol 154:2291-2302. Medline

David S, Kroner A (2011) Repertoire of microglial and macrophage responses after spinal cord injury. Nat Rev Neurosci 12:388-399. CrossRef Medline

Díaz-González F, González-Alvaro I, Campanero MR, Mollinedo F, del Pozo MA, Muñoz C, Pivel JP, Sánchez-Madrid F (1995) Prevention of in vitro neutrophil-endothelial attachment through shedding of L-selectin by nonsteroidal antiinflammatory drugs. J Clin Invest 95:1756-1765. CrossRef Medline

Díaz-González F, Sánchez-Madrid F (2015) NSAIDs: learning new tricks from old drugs. Eur J Immunol 45:679-686. CrossRef

Donnelly DJ, Longbrake EE, Shawler TM, Kigerl KA, Lai W, Tovar CA, Ransohoff RM, Popovich PG (2011) Deficient CX3CR1 signaling promotes recovery after mouse spinal cord injury by limiting the recruitment and activation of Ly6Clo/iNOS+ macrophages. J Neurosci 31:9910-9922. CrossRef Medline

Esterbauer H, Schaur RJ, Zollner H (1991) Chemistry and biochemistry of 4-hydroxynonenal, malonaldehyde and related aldehydes. Free Radic Biol Med 11:81-128. Medline

Gómez-Gaviro MV, González-Alvaro I, Domínguez-Jiménez C, Peschon J, Black RA, Sánchez-Madrid F, Díaz-González F (2002) Structure-function relationship and role of tumor necrosis factoralpha-converting enzyme in the down-regulation of L-selectin by non-steroidal anti-inflammatory drugs. J Biol Chem 277:3821238221. CrossRef Medline

Gonzalez R, Glaser J, Liu MT, Lane TE, Keirstead HS (2003) Reducing inflammation decreases secondary degeneration and functional deficit after spinal cord injury. Exp Neurol 184:456-463. Medline

Grace RF, Lin Y, Edwards SR, Power I, Mather LE (2001) Effects of diclofenac in the rat tail ischaemia-reperfusion injury model of acute hyperalgesia. Pain 89:117-125. Medline

Grewal IS, Foellmer HG, Grewal KD, Wang H, Lee WP, Tumas D, Janeway CA Jr, Flavell RA (2001) CD62L is required on effector cells for local interactions in the CNS to cause myelin damage in experimental allergic encephalomyelitis. Immunity 14:291-302. CrossRef

Gris D, Marsh DR, Oatway MA, Chen Y, Hamilton EF, Dekaban GA, Weaver LC (2004) Transient blockade of the CD11d/CD18 integrin reduces secondary damage after spinal cord injury, improving sensory, autonomic, and motor function. J Neurosci 24:40434051. CrossRef Medline

Hamada Y, Ikata T, Katoh S, Nakauchi K, Niwa M, Kawai Y, Fukuzawa K (1996) Involvement of an intercellular adhesion molecule 1-dependent pathway in the pathogenesis of secondary changes after spinal cord injury in rats. J Neurochem 66:1525-1531. Medline

Herrera-García A, Domínguez-Luis M, Arce-Franco M, LópezFernández J, Feria $M$, Barreiro $O$, Sánchez-Madrid $F$, DíazGonzález F (2013) In vivo modulation of the inflammatory response by nonsteroidal antiinflammatory drug-related compounds that trigger L-selectin shedding. Eur J Immunol 43:55-64. CrossRef Medline

Hichor M, Sundaram VK, Eid SA, Abdel-Rassoul R, Petit PX, Borderie D, Bastin J, Eid AA, Manuel M, Grenier J, Massaad C (2018) Liver $X$ receptor exerts a protective effect against the oxidative stress in the peripheral nerve. Sci Rep 8:2524. CrossRef Medline

Huang K, Geoffroy JS, Singer MS, Rosen SD (1991) A lymphocyte homing receptor (L-selectin) mediates the in vitro attachment of lymphocytes to myelinated tracts of the central nervous system. $J$ Clin Invest 88:1778-1783. CrossRef Medline

Huang K, Kikuta A, Rosen SD (1994) Myelin localization of a central nervous system ligand for L-selectin. J Neuroimmunol 53:133141. Medline

Hurtado A, Marcillo A, Frydel B, Bunge MB, Bramlett HM, Dietrich WD (2012) Anti-CD11d monoclonal antibody treatment for rat spinal cord compression injury. Exp Neurol 233:606-611. CrossRef Medline 
Kuhn PL, Wrathall JR (1998) A mouse model of graded contusive spinal cord injury. J Neurotrauma 15:125-140. CrossRef Medline

Kwon BK, Okon E, Hillyer J, Mann C, Baptiste D, Weaver LC, Fehlings MG, Tetzlaff W (2011) A systematic review of noninvasive pharmacologic neuroprotective treatments for acute spinal cord injury. J Neurotrauma 28:1545-1588. CrossRef Medline

Lee SM, Rosen S, Weinstein P, van Rooijen N, Noble-Haeusslein LJ (2011) Prevention of both neutrophil and monocyte recruitment promotes recovery after spinal cord injury. J Neurotrauma 28: 1893-1907. CrossRef Medline

Lewinsohn DM, Bargatze RF, Butcher EC (1987) Leukocyteendothelial cell recognition: evidence of a common molecular mechanism shared by neutrophils, lymphocytes, and other leukocytes. J Immunol 138:4313-4321. Medline

Ley K, Laudanna C, Cybulsky MI, Nourshargh S (2007) Getting to the site of inflammation: the leukocyte adhesion cascade updated. Nat Rev Immunol 7:678-689. CrossRef Medline

Li Y, Brazzell J, Herrera A, Walcheck B (2006) ADAM17 deficiency by mature neutrophils has differential effects on L-selectin shedding. Blood 108:2275-2279. CrossRef Medline

Lin Y, Vreman HJ, Wong RJ, Tjoa T, Yamauchi T, Noble-Haeusslein LJ (2007) Heme oxygenase-1 stabilizes the blood-spinal cord barrier and limits oxidative stress and white matter damage in the acutely injured murine spinal cord. J Cereb Blood Flow Metab 27:1010-1021. CrossRef Medline

Liu D, Li L, Augustus L (2001) Prostaglandin release by spinal cord injury mediates production of hydroxyl radical, malondialdehyde and cell death: a site of the neuroprotective action of methylprednisolone. J Neurochem 77:1036-1047. Medline

Mahajan VS, Demissie E, Mattoo H, Viswanadham V, Varki A, Morris R, Pillai S (2016) Striking immune phenotypes in gene-targeted mice are driven by a copy-number variant originating from a commercially available C57BL/6 strain. Cell Rep 15:1901-1909. CrossRef Medline

McEver RP (2015) Selectins: initiators of leucocyte adhesion and signalling at the vascular wall. Cardiovasc Res 107:331-339. CrossRef Medline

Mohanty T, Sjögren J, Kahn F, Abu-Humaidan AH, Fisker N, Assing K, Mörgelin M, Bengtsson AA, Borregaard N, Sørensen OE (2015) A novel mechanism for NETosis provides antimicrobial defense at the oral mucosa. Blood 126:2128-2137. CrossRef Medline

Morikis VA, Chase S, Wun T, Chaikof EL, Magnani JL, Simon SI (2017) Selectin catch-bonds mechanotransduce integrin activation and neutrophil arrest on inflamed endothelium under shear flow. Blood 130:2101-2110. CrossRef Medline

Nair AB, Jacob S (2016) A simple practice guide for dose conversion between animals and human. J Basic Clin Pharm 7:27-31. CrossRef Medline

Noble LJ, Donovan F, Igarashi T, Goussev S, Werb Z (2002) Matrix metalloproteinases limit functional recovery after spinal cord injury by modulation of early vascular events. J Neurosci 22:7526-7535. Medline

Pizcueta P, Luscinskas FW (1994) Monoclonal antibody blockade of L-selectin inhibits mononuclear leukocyte recruitment to inflammatory sites in vivo. Am J Pathol 145:461-469. Medline

Popovich PG, Guan Z, Wei P, Huitinga I, van Rooijen N, Stokes BT (1999) Depletion of hematogenous macrophages promotes partial hindlimb recovery and neuroanatomical repair after experimental spinal cord injury. Exp Neurol 158:351-365. CrossRef Medline

Popovich PG, Longbrake EE (2008) Can the immune system be harnessed to repair the CNS? Nat Rev Neurosci 9:481-493. CrossRef Medline

Ransohoff RM, Kivisäkk P, Kidd G (2003) Three or more routes for leukocyte migration into the central nervous system. Nat Rev Immunol 3:569-581. CrossRef Medline

Rosen SD (2004) Ligands for L-selectin: homing, inflammation, and beyond. Annu Rev Immunol 22:129-156. CrossRef Medline

Saiwai H, Ohkawa Y, Yamada H, Kumamaru H, Harada A, Okano H, Yokomizo T, Iwamoto Y, Okada S (2010) The LTB4-BLT1 axis mediates neutrophil infiltration and secondary injury in experimental spinal cord injury. Am J Pathol 176:2352-2366. CrossRef Medline

Schaar KL, Brenneman MM, Savitz SI (2010) Functional assessments in the rodent stroke model. Exp Transl Stroke Med 2:13. CrossRef Medline

Scholer DW, Ku EC, Boettcher I, Schweizer A (1986) Pharmacology of diclofenac sodium. Am J Med 80:34-38. Medline

Shao B, Wahrenbrock MG, Yao L, David T, Coughlin SR, Xia L, Varki A, McEver RP (2011) Carcinoma mucins trigger reciprocal activation of platelets and neutrophils in a murine model of Trousseau syndrome. Blood 118:4015-4023. CrossRef

Simon SI, Chambers JD, Butcher E, Sklar LA (1992) Neutrophil aggregation is beta 2-integrin- and L-selectin-dependent in blood and isolated cells. J Immunol 149:2765-2771. Medline

Sperandio M, Smith ML, Forlow SB, Olson TS, Xia L, McEver RP, Ley K (2003) P-selectin glycoprotein ligand-1 mediates L-selectindependent leukocyte rolling in venules. J Exp Med 197:13551363. CrossRef Medline

Stadtmann A, Germena G, Block H, Boras M, Rossaint J, Sundd P, Lefort C, Fisher Cl, Buscher K, Gelschefarth B, Urzainqui A, Gerke V, Ley K, Zarbock A (2013) The PSGL-1-L-selectin signaling complex regulates neutrophil adhesion under flow. J Exp Med 210: 2171-2180. CrossRef

Stirling DP, Yong VW (2008) Dynamics of the inflammatory response after murine spinal cord injury revealed by flow cytometry. J Neurosci Res 86:1944-1958. CrossRef Medline

Stirling DP, Liu S, Kubes P, Yong VW (2009) Depletion of Ly6G/Gr-1 leukocytes after spinal cord injury in mice alters wound healing and worsens neurological outcome. J Neurosci 29:753-764. CrossRef Medline

Strausbaugh HJ, Green PG, Lo E, Tangemann K, Reichling DB, Rosen SD, Levine JD (1999) Painful stimulation suppresses joint inflammation by inducing shedding of $L$-selectin from neutrophils. Nat Med 5:1057-1061. CrossRef Medline

Taoka Y, Okajima K, Uchiba M, Murakami K, Kushimoto S, Johno M, Naruo M, Okabe H, Takatsuki K (1997) Role of neutrophils in spinal cord injury in the rat. Neuroscience 79:1177-1182. Medline

Tedder TF, Steeber DA, Pizcueta P (1995) L-selectin-deficient mice have impaired leukocyte recruitment into inflammatory sites. J Exp Med 181:2259-2264. Medline

Walcheck B, Moore KL, McEver RP, Kishimoto TK (1996) Neutrophilneutrophil interactions under hydrodynamic shear stress involve L-selectin and PSGL-1. A mechanism that amplifies initial leukocyte accumulation of P-selectin in vitro. J Clin Invest 98:10811087. CrossRef Medline

Whetstone WD, Walker B, Trivedi A, Lee S, Noble-Haeusslein LJ, Hsu JC (2017) Protease-activated receptor-1 supports locomotor recovery by biased agonist activated protein $C$ after contusive spinal cord injury. PLoS One 12:e0170512. CrossRef Medline

Zarbock A, Ley K (2008) Mechanisms and consequences of neutrophil interaction with the endothelium. Am J Pathol 172:1-7. CrossRef Medline

Zarbock A, Ley K, McEver RP, Hidalgo A (2011) Leukocyte ligands for endothelial selectins: specialized glycoconjugates that mediate rolling and signaling under flow. Blood 118:6743-6751. CrossRef Medline

Zhang H, Trivedi A, Lee JU, Lohela M, Lee SM, Fandel TM, Werb Z, Noble-Haeusslein LJ (2011) Matrix metalloproteinase-9 and stromal cell-derived factor- 1 act synergistically to support migration of blood-borne monocytes into the injured spinal cord. J Neurosci 31:15894-15903. CrossRef Medline

Zuchtriegel G, Uhl B, Hessenauer ME, Kurz AR, Rehberg M, Lauber K, Krombach F, Reichel CA (2015) Spatiotemporal expression dynamics of selectins govern the sequential extravasation of neutrophils and monocytes in the acute inflammatory response. Arterioscler Thromb Vasc Biol 35:899-910. CrossRef Medline 